\title{
Article \\ Characteristics of Low Band Gap Copolymers Containing Anthracene-Benzothiadiazole Dicarboxylic Imide: Synthesis, Optical, Electrochemical, Thermal and Structural Studies
}

\author{
Ary R. Murad ${ }^{1}$, Ahmed Iraqi ${ }^{2}{ }^{(}$, Shujahadeen B. Aziz ${ }^{3,4, *}{ }^{-1}$, Mohammed S. Almeataq ${ }^{5}$, Sozan N. Abdullah ${ }^{6}$ and \\ Mohamad A. Brza ${ }^{7}$ \\ 1 Department of Pharmaceutical Chemistry, College of Medical and Applied Sciences, Charmo University, \\ Chamchamal 46023, Iraq; ary.murad@charmouniversity.org \\ 2 Department of Chemistry, University of Sheffield, Sheffield S3 7HF, UK; a.iraqi@sheffield.ac.uk \\ 3 Hameed Majid Advanced Polymeric Materials Research Lab., Department of Physics, College of Science, \\ University of Sulaimani, Sulaimani 46001, Iraq \\ 4 Department of Civil Engineering, College of Engineering, Komar University of Science and Technology, \\ Sulaimani 46001, Iraq \\ 5 King Abdulaziz City for Science and Technology, Riyadh 11451, Saudi Arabia; mmeataq@kacst.edu.sa \\ 6 Department of Chemistry, College of Science, University of Sulaimani, Sulaimani 46001, Iraq; \\ sozan.abdulla@univsul.edu.iq \\ 7 Department of Manufacturing and Materials Engineering, Faculty of Engineering, International Islamic \\ University of Malaysia, Kuala Lumpur 53100, Malaysia; mohamad.brza@gmail.com \\ * Correspondence: shujahadeenaziz@gmail.com
}

Citation: Murad, A.R.; Iraqi, A.; Aziz S.B.; Almeataq, M.S.; Abdullah, S.N.; Brza, M.A. Characteristics of Low Band Gap Copolymers Containing Anthracene-Benzothiadiazole Dicarboxylic Imide: Synthesis, Optical, Electrochemical, Thermal and Structural Studies. Polymers 2021, 13, 62. https://doi.org/10.3390/ polym13010062

Received: 26 November 2020 Accepted: 22 December 2020 Published: 25 December 2020

Publisher's Note: MDPI stays neutral with regard to jurisdictional clai$\mathrm{ms}$ in published maps and institutional affiliations.

Copyright: (C) 2020 by the authors. Licensee MDPI, Basel, Switzerland. This article is an open access article distributed under the terms and conditions of the Creative Commons Attribution (CC BY) license (https:// creativecommons.org/licenses/by/ $4.0 /)$
Abstract: Two novel low band gap donor-acceptor (D-A) copolymers, poly[9,10-bis(4-(dodecyloxy)phenyl)-2,6-anthracene-alt-5,5-(4' , $7^{\prime}$-bis(2-thienyl)-2' ${ }^{\prime} 1^{\prime}, 3^{\prime}$-benzothiadiazole- $N$-5,6-(3,7-dimethyloctyl)dicarboxylic imide)] (PPADTBTDI-DMO) and poly[9,10-bis(4-(dodecyloxy)phenyl)-2,6-anthracenealt-5,5-(4', $7^{\prime}$-bis(2-thienyl)-2' $1^{\prime} 1^{\prime}, 3^{\prime}$-benzothiadiazole-5,6- $N$-octyl-dicarboxylic imide)] (PPADTBTDI-8) were synthesized in the present work by copolymerising the bis-boronate ester of 9,10-phenylsubstituted anthracene flanked by thienyl groups as electron-donor units with benzothiadiazole dicarboxylic imide (BTDI) as electron-acceptor units. Both polymers were synthesized in good yields via Suzuki polymerisation. Two different solubilizing alkyl chains were anchored to the BTDI units in order to investigate the impact upon their solubilities, molecular weights, optical and electrochemical properties, structural properties and thermal stability of the resulting polymers. Both polymers have comparable molecular weights and have a low optical band gap $\left(\mathrm{E}_{\mathrm{g}}\right)$ of $1.66 \mathrm{eV}$. The polymers have low-lying highest occupied molecular orbital (HOMO) levels of about $-5.5 \mathrm{eV}$ as well as the similar lowest unoccupied molecular orbital (LUMO) energy levels of $-3.56 \mathrm{eV}$. Thermogravimetric analyses (TGA) of PPADTBTDI-DMO and PPADTBTDI-8 did not prove instability with decomposition temperatures at 354 and $313^{\circ} \mathrm{C}$, respectively. Powder X-ray diffraction (XRD) studies have shown that both polymers have an amorphous nature in the solid state, which could be used as electrolytes in optoelectronic devices.

Keywords: conjugated copolymers; optical study; electrochemical properties; thermal properties; powder X-ray diffraction (XRD) analysis

\section{Introduction}

Organic solar cells are a promising alternative to traditional inorganic semiconducting materials [1,2]. Efforts have been made to design new materials for application in optoelectronic devices such as field effect transistors (FETs) [3,4], light-emitting diodes [5,6], and photovoltaic cells [7]. Research into the development of novel compounds-based anthracene started in 1963 when the Pope and co-workers investigated electroluminescence in anthracene crystals [8]. Anthracene and its derivatives along with the other acenes like 
tetracene [9] and pentacene [10] have been extensively studied in organic FETs [11]. These materials have good hole mobilities owing to the strong intermolecular interactions in their planar and rigid structures [12].

Anthracene is one of the interesting building blocks as an electron donor unit to construct the medium band gap D-A copolymers for photovoltaic applications [13]. Anthracene has a weak electron-donating ability, therefore anthracene-based D-A copolymers are expected to have low-lying HOMO levels, which are beneficial to obtain high opencircuit voltage $\left(V_{\text {oc }}\right)$ values in bulk heterojunction polymer solar cells (BHJ PSCs) [14]. In addition, anthracene could be incorporated into the conjugated polymer chains through its 2,6-positions or 9,10-positions [15,16]. Polymerizing anthracene through its 2,6-positions provides the 9,10-positions for attaching different solubilizing side chains which result in a better processability of the polymers [13]. Anthracene and its derivatives have been widely applied in polymer light-emitting diodes (PLEDs) [17] and FETs [18], while few reports have been published for anthracene in PSCs [19].

Sonar et al. synthesized a D-A copolymer poly[3,6-difuran-2-yl-2,5-di(2-octyldodecyl)pyrrolo[3,4-c]pyrrole-1,4-dione-alt-anthracene] (PDPP-FAF) by copolymerizing diketopyrrolopyrrole (DPP) with 2,6-linked anthracene and two furan units as spacers between donor and acceptor units. BHJ PSCs based on PDPP-FAF: $\mathrm{PC}_{71} \mathrm{BM}$ gave a power conversion (PC) efficiency of $2.5 \%$ [20].

Iraqi and co-workers developed three alternating copolymers, poly(9,10-bis(4-(dodecyloxy)phenyl)-anthracene-2,6-diyl-alt-(4,7-dithiophen-2-yl)-2' $, 1^{\prime}, 3^{\prime}$-benzothiadiazole-5,5-diyl] (PPATBT), poly(9,10-bis(4-(dodecyloxy)phenyl)-anthracene-2,6-diyl-alt-(5,6-bis(octyloxy)4,7-di(thiophen-2-yl)benzo[c][1,2,5]thiadiazole-5,5-diyl] (PPATBT-8) and poly(9,10-bis(4(dodecyloxy)phenyl)-anthracene-2,6-diyl-alt-(5,6-bis(octyloxy)-4,7-di(2,2'-bithiophen-5-yl)benzo[c][1,2,5] thiadiazole)-5,5-diyl] (PPAT2BT-8), comprising 9,10-phenylanthracene as donor units and various 2,1,3-benzothiadiazole (BT) as acceptor units [21]. PPATBT, PPATBT8, and PPAT2BT-8 have an $\mathrm{E}_{\mathrm{g}}$ of $1.84,1.96$ and $1.86 \mathrm{eV}$, respectively. The photovoltaic performance of PPATBT is less than $2 \%$ because of its poor solubility. However, PPATBT- 8 and PPAT2BT- 8 have the PC efficiencies of 3.92 and $4.17 \%$ when mixed with $\mathrm{PC}_{71} \mathrm{BM}$ as the acceptor, respectively. Iraqi et al. also reported three new copolymers, poly[9,10bis(triisopropylsilylacetylene)-anthracene-2,6-diyl-alt-(4,7-dithiophen-2-yl)-5,6-difluorobenzo[c][1,2,5]thiadiazole-5-5-diyl] (PTATffBT), poly[9,10-bis(triisopropylsilylacetylene)anthracene-2,6-diylalt-(5,6-bis(octyloxy)-4,7-di(thiophene-2-yl)benzo[c]thiadiazole-5,5-diyl] (PTATBT-8) and poly(9,10-bis(triisopropylsilylacetylene)-anthracene-2,6-diylalt-(5,6-bis(octyloxy)-4,7-di(2,2'-bithiophen-5-yl)benzo[c][1,2,5]thiadiazole)-5,5-diyl] (PTAT2BT-8) [22]. The copolymers were synthesised by Suzuki polymerisation between 2,6-linked anthracene and various 2,1,3-benzothiadiazole acceptor units. Anthracene was functionalized with triisopropylsilylacetylene (TIPS) at its 9,10-positions. The $\mathrm{E}_{\mathrm{g}}$ of the polymers are in the range of 1.81-1.92 eV. The PTATffBT has the deep-lying HOMO but high-lying LUMO energy levels compared to its PTATBT- 8 and PTAT2BT- 8 analogues. BHJ solar cell based on PTATBT-8: $\mathrm{PC}_{71} \mathrm{BM}$ has the PC efficiency of $2.36 \%$. On the contrary, PTAT2BT- 8 fabricated with $\mathrm{PC}_{71} \mathrm{BM}$ provides the higher PC efficiency of $3.15 \%$.

Anthracene functionalized at 9,10-positions with dodecyloxy, dodecylthienyl and dodecylphenyl side chains were copolymerized through 2,6-positions with BT bearing dodecyloxy and octyloxy substituents yield POA12OTBT, PTA12OTBT, PBA12OTBT, POA8OTBT, PTA8OTBT and PBA8OTBT, respectively [19]. The $\mathrm{E}_{\mathrm{g}}$ of the two dimensional (2D) conjugated polymers with thienyl and phenyl chains on anthracene unit are comparable (ca. $1.85 \mathrm{eV}$ ), which are much lower than those copolymers with dodecyloxy chains on the anthracene unit (ca. $2.13 \mathrm{eV}$ ). The 2D-conjugated polymers have deeper HOMO energy levels relative to those with dodecyloxy chains. Therefore, the $V_{\mathrm{oc}}$ values of the former polymers are higher than the latter polymers. The hole mobilities of POA12OTBT and POA8OTBT are lower than the polymers with the aromatic side group analogues. As a result, short-circuit current $\left(J_{\mathrm{sc}}\right)$ values of the latter polymers are higher than the former polymers. POA8OTBT and POA12OTBT fabricated with $\mathrm{PC}_{71} \mathrm{BM}$ deliver the PC efficien- 
cies of 1.82 and $2.26 \%$, respectively. However, 2D-conjugated polymers provide the PC efficiency higher than $3 \%$ under the same experimental conditions. PBA8OTBT yields the highest PC efficiency of $4.34 \%$.

Jo et al. reported four alternating copolymers, PTADTBT, PTADTFBT, PTADTDFBT and PTADTBTO. The copolymers were synthesised by Stille polymerisation between 9,10thienylanthracene (TA) and BT with different substituents at 5,6-positions [13]. The $\mathrm{E}_{\mathrm{g}}$ of the polymers are in the range of 1.8-2.1 eV and PTADTBTO has the highest $\mathrm{E}_{\mathrm{g}}$ among all polymers prepared. The HOMO levels of the polymers are between -5.38 and $-5.55 \mathrm{eV}$, while the PTADTDFBT exhibits the deepest HOMO energy level. The LUMO energy levels of PTADTBT, PTADTFBT and PTADTDFBT are comparable around $-3.6 \mathrm{eV}$ but PTADTBTO shows the highest LUMO level of $-3.28 \mathrm{eV}$. PTADTBTO blended with $\mathrm{PC}_{71} \mathrm{BM}$ delivers the PC efficiency of $4.64 \%$. However, PTADTBT and PTADTFBT blended with $\mathrm{PC}_{71} \mathrm{BM}$ provide the PC efficiency of 6.92 and $7.27 \%$, respectively. PTADTDFBT yields the highest PC efficiency up to $8 \%$.

Later on, Jo and co-workers further developed two novel D-A copolymers, PTATDPP and PTAFDPP, based on 9,10-thienyl substituted anthracene and DPP, respectively [23]. PTATDPP and PTAFDPP show the same $E_{g}$ of $1.61 \mathrm{eV}$. They exhibit a high degree of crystallinity as confirmed by XRD studies. As a consequence, PTATDPP and PTAFDPP deliver high hole mobilities measured by FETs. PTAFDPP fabricated with $\mathrm{PC}_{71} \mathrm{BM}$ shows the PC efficiency of $5.22 \%$. On the other hand, PTATDPP: $\mathrm{PC}_{71} \mathrm{BM}$ provides much higher PC efficiency up to $7 \%$ under the same experimental conditions.

The synthetic methods for the preparation of benzothiadiazole dicarboxylic imide (BTDI) monomers (M1 and M2) are outlined in Scheme 1. M1 and M2 were synthesised through several steps starting from commercially available thiophene. For the synthesis of 2,5-dibromothiophene (1), thiophene was selectively brominated at 2,5-positions using two equivalents of $\mathrm{N}$-bromosuccinimide (NBS) in $N, N$-dimethylformamide (DMF) in the dark to give material 1 as a yellow oily product in a high yield [24]. Then, material 1 was nitrated with concentrated nitric acid/sulfuric acid and fuming sulfuric acid to give 2,5-dibromo-3,4-dinitrothiophene (2) [25-27]. The compound 2 was then reacted with 2-(tributylstannyl)thiophene in the presence of $\mathrm{PdCl}_{2}\left(\mathrm{PPh}_{3}\right)_{2}$ as a catalyst in anhydrous toluene at $115^{\circ} \mathrm{C}$ to give $3^{\prime}, 4^{\prime}$-dinitro-2, $2^{\prime}: 5^{\prime}, 2^{\prime \prime}$-terthiophene (3). The resulting compound was obtained as orange crystals in a good yield of $90 \%$ [28]. $3^{\prime}, 4^{\prime}$-diamino$2,2^{\prime}: 5,2^{\prime \prime}$-terthiophene (4) was obtained by a reduction reaction of material 3 using excess anhydrous tin (II) chloride $\left(\mathrm{SnCl}_{2}\right)$. Material 4 was achieved as a brown solid in a good yield of $97 \%$ [29]. The resulting substance (4) was then reacted with $N$-thionyl aniline (PhNSO) and trimethylsilyl chloride (TMSCl) in anhydrous pyridine to afford 4,6-bis(2thienyl)-thieno[3,4-c][1,2,5]-thiadiazole (5) as blue crystals in a good yield of 93\% [30]. The compound 4,7-di(thien-2-yl)-2,1,3-benzothiadiazole-5,6-dimethyl ester (6) was obtained by the Diels-Alder reaction between material 5 and dimethyl acetylenedicarboxylate in anhydrous xylene at reflux. It was obtained in a good yield of $94 \%$ as yellow crystals [31]. Then, the material 6 was hydrolysed under basic conditions in ethanol under reflux followed by acidification to yield 4,7-di(thien-2-yl)-2,1,3-benzothiadiazole-5,6-dicarboxylic acid (7) as a yellow solid in a yield of 85\% [32]. The compound 4,7-di(thien-2-yl)-2,1,3benzothiadiazole-5,6-dicarboxylic anhydride (8) was synthesised by the intramolecular ring closure of material 7 , in the presence of acetic anhydride and anhydrous xylene at $130{ }^{\circ} \mathrm{C}$, to afford material 8 as a red solid in a good yield of $97 \%$ [33]. Moreover, 3,7dimethyloctyl bromide (9) was synthesized from the reaction of commercially available 3,7-dimethyl-1-octanol with triphenylphosphine $\left(\mathrm{Ph}_{3} \mathrm{P}\right) / \mathrm{NBS}$ in dichloromethane to yield material 9 as a colourless oil in 73\% yield [34]. Then, material 9 was reacted with potassium phthalimide in anhydrous DMF to give $N$-(3,7-dimethyloctyl)phthalimide (10) as colourless oil in a good yield of 91\% [35]. In addition, 3,7-dimethyl-1-octanamine (11) was obtained by Gabriel synthesis from the reaction of material 10 with hydrazine hydrate $\left(\mathrm{NH}_{2} \mathrm{NH}_{2}\right)$ in methanol as a brown oil in $86 \%$ yield [36]. The compounds 4,7-di(thien-2-yl)2,1,3-benzothiadiazole-5,6-N-(3,7-dimethyloctyl) dicarboxylic imide (12) and 4,7-di(thien- 
2-yl)-2,1,3-benzothiadiazole-5,6- $\mathrm{N}$-octyl-dicarboxylic imide (13) were synthesized by the reaction of material 8 with material 11 and 1-octanamine in the presence of acetic acid and acetic anhydride to yield imide functionalized monomers (12 and 13) as orange solids in 84 and 93\% yield, respectively. Lastly, the monomers 4,7-di(5-bromo-thien-2-yl)-2,1,3benzothiadiazole-5,6-N-(3,7-dimethyloctyl)dicarboxylic imide (M1) and 4,7-di(5-bromothien-2-yl)-2,1,3-benzothiadiazole-5,6-N-octyl-dicarboxylic imide (M2) were prepared by the bromination of material 12 and material 13 at 5,5'-positions using NBS in tetrahydrofuran (THF) and to yield M1 and M2 as red solids in good yields of 98 and 96\%, respectively.

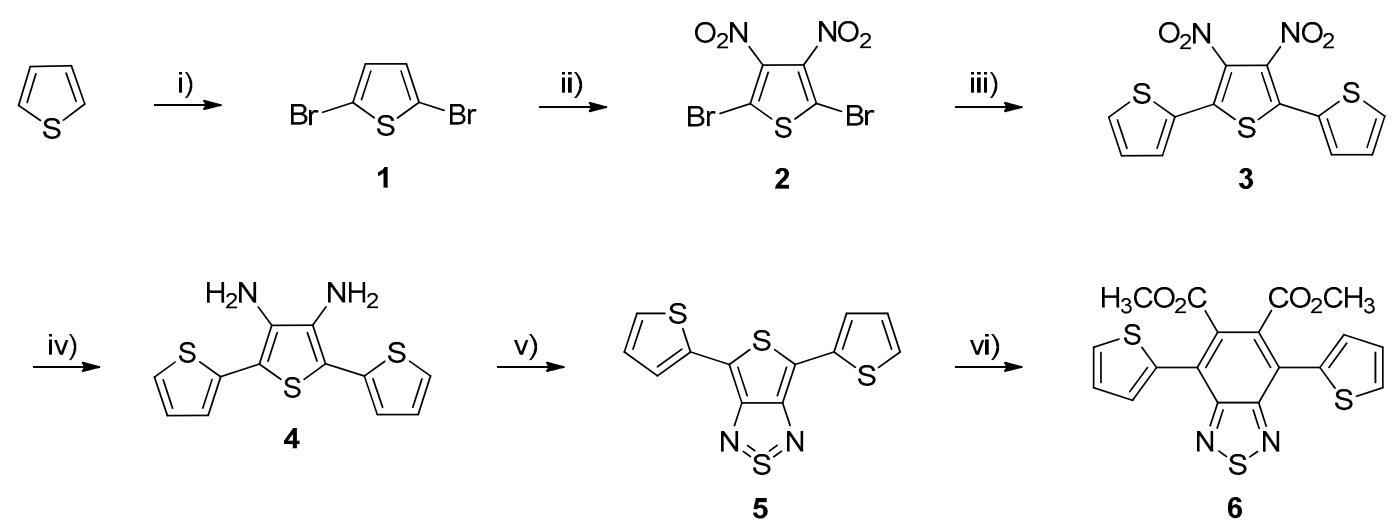

$\stackrel{\text { vii) }}{\longrightarrow}$<smiles>O=C(O)c1c(-c2cccs2)c(C(=O)O)c2nsnc2c1-c1cccs1</smiles><smiles>O=C1OC(=O)c2c(-c3cccs3)c3n[se]nc3c(-c3cccs3)c1c2=O</smiles>

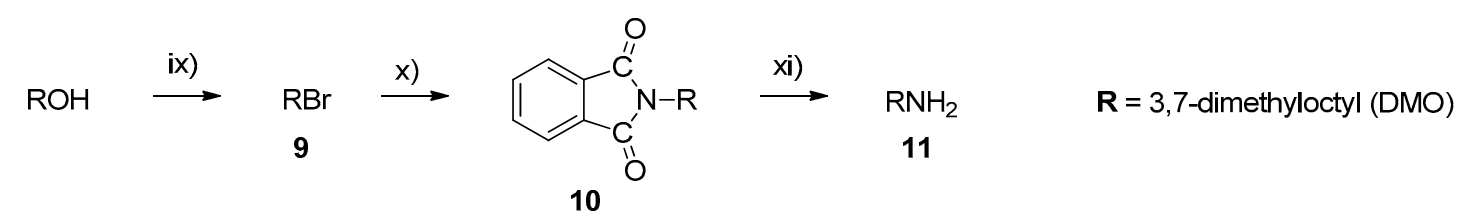

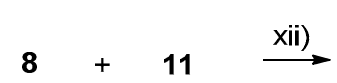<smiles>[R]N1C(=O)c2c(-c3cccs3)c(-c3cccs3)c3nsnc3c2C1=O</smiles>

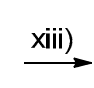<smiles>[R]N1C(=O)c2c(c(-c3ccc(Br)s3)c3nsnc3c2-c2ccc(Br)s2)C1=O</smiles>

12: $R=D M O$

M1: $R=D M O$

13: $R=$ octyl

M2: $R=$ octyl

Scheme 1. Synthetic steps of M1 and M2.

Reagents and conditions:

i) NBS, DMF, $-15^{\circ} \mathrm{C}$, room temperature, overnight;

ii) Fuming $\mathrm{H}_{2} \mathrm{SO}_{4}\left(20 \%\right.$ free $\left.\mathrm{SO}_{3}\right)$, conc. $\mathrm{H}_{2} \mathrm{SO}_{4}$, conc. $\mathrm{HNO}_{3}, 20^{\circ} \mathrm{C}, 20-30{ }^{\circ} \mathrm{C}, 3 \mathrm{~h}$;

iii) 2-(tributylstannyl)thiophene, anhydrous toluene, $\mathrm{PdCl}_{2}\left(\mathrm{PPh}_{3}\right)_{2}, 115{ }^{\circ} \mathrm{C}, 24 \mathrm{~h}$;

iv) Anhydrous $\mathrm{SnCl}_{2}, \mathrm{HCl}(35 \%)$, ethanol, $30{ }^{\circ} \mathrm{C}, 24 \mathrm{~h}, \mathrm{NaOH}(25 \%)$;

v) $\mathrm{PhNSO}, \mathrm{TMSCl}$, anhydrous pyridine, $3 \mathrm{~h}, \mathrm{RT}, \mathrm{HCl}(1.0 \mathrm{~N})$;

vi) Dimethyl acetylenedicarboxylate, anhydrous xylene, reflux $24 \mathrm{~h}$;

vii) Aqueous $\mathrm{NaOH}$, ethanol, reflux $24 \mathrm{~h}, \mathrm{HCl}(35 \%)$;

viii) Anhydrous $\mathrm{Ac}_{2} \mathrm{O}$, anhydrous xylene, $130{ }^{\circ} \mathrm{C}, 6 \mathrm{~h}$; ix) dichloromethane (DCM), $\mathrm{PPh}_{3}$, NBS, RT, 90 min; 
ix) Potassium phthalimide, anhydrous $\mathrm{DMF}, 90^{\circ} \mathrm{C}, 17 \mathrm{~h}, \mathrm{KOH}$;

x) Hydrazine hydrate (51\%), methanol, reflux, $\mathrm{HCl}(5.0 \mathrm{M})$, reflux, $1 \mathrm{~h}$;

xi) $\mathrm{HOAc}(100 \%), 100{ }^{\circ} \mathrm{C}$ overnight, $\mathrm{Ac}_{2} \mathrm{O}, 100{ }^{\circ} \mathrm{C}, 6 \mathrm{~h}$;

xii) NBS, THF, RT, overnight.

In this work, the preparation and characterisation of two alternating copolymers, PPADTBTDI-DMO and PPADTBTDI-8, are presented. The polymers were synthesised via the Suzuki polymerisation between the diboronic ester of 2,6-linked anthracene (M3) and dibrominated BTDI monomers (M1 and M2), respectively (Scheme 2). The polymerisations were performed with palladium(II) acetate $\left[\mathrm{Pd}(\mathrm{OAc})_{2}\right] /$ tri $(o$-tolyl $)$ phosphine $\left[\mathrm{P}(o \text {-tol })_{3}\right]$ catalyst, sodium hydrogen carbonate $\left(\mathrm{NaHCO}_{3}\right)$ base in anhydrous THF [37]. Both polymerisations were left for 23-24 $\mathrm{h}$ with large amounts of purple precipitates forming as the reactions proceeded. The polymers were then dissolved in chloroform and an ammonia solution added then to the mixture stirred overnight to remove the palladium metal catalyst residues by forming tetraamminepalladium (II) dihydroxide $\left[\mathrm{Pd}\left(\mathrm{NH}_{3}\right)_{4}(\mathrm{OH})_{2}\right]$ soluble complexes. The polymers were obtained by precipitation from methanol followed by filtration. The polymers purified via Soxhlet extraction with methanol, acetone, hexane, toluene and finally chloroform. The small molecules, oligomers and impurities were removed in the methanol, acetone and hexane fractions. The toluene and chloroform fractions of the polymers were subsequently collected and concentrated in vacuo, re-precipitated in methanol followed by filtration to yield the purified polymers. The structures of PPADTBTDI-DMO and PPADTBTDI-8 were confirmed by the ${ }^{1} \mathrm{H}$ NMR spectroscopy, FT-IR spectroscopy and elemental analysis. The ${ }^{1} \mathrm{H}$ NMR spectra of the polymers are shown in Figures 1 and 2.

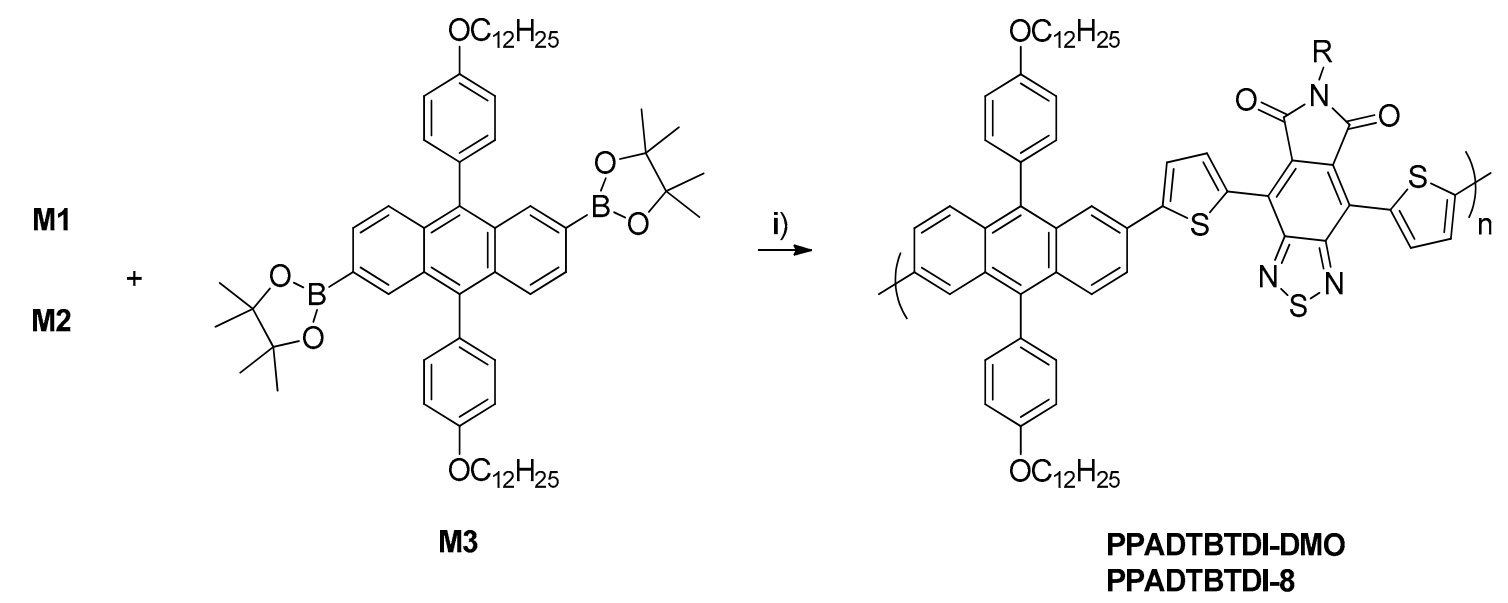

Scheme 2. The synthesis of PPADTBTDI-DMO and PPADTBTDI-8 via Suzuki polymerisation. $23-24 \mathrm{~h}$.

Reagents and conditions: (i) anhydrous THF, $\mathrm{NaHCO}_{3}, \mathrm{Pd}(\mathrm{OAc})_{2}, \mathrm{P}(o-\text { tol })_{3}, 90{ }^{\circ} \mathrm{C}$, 


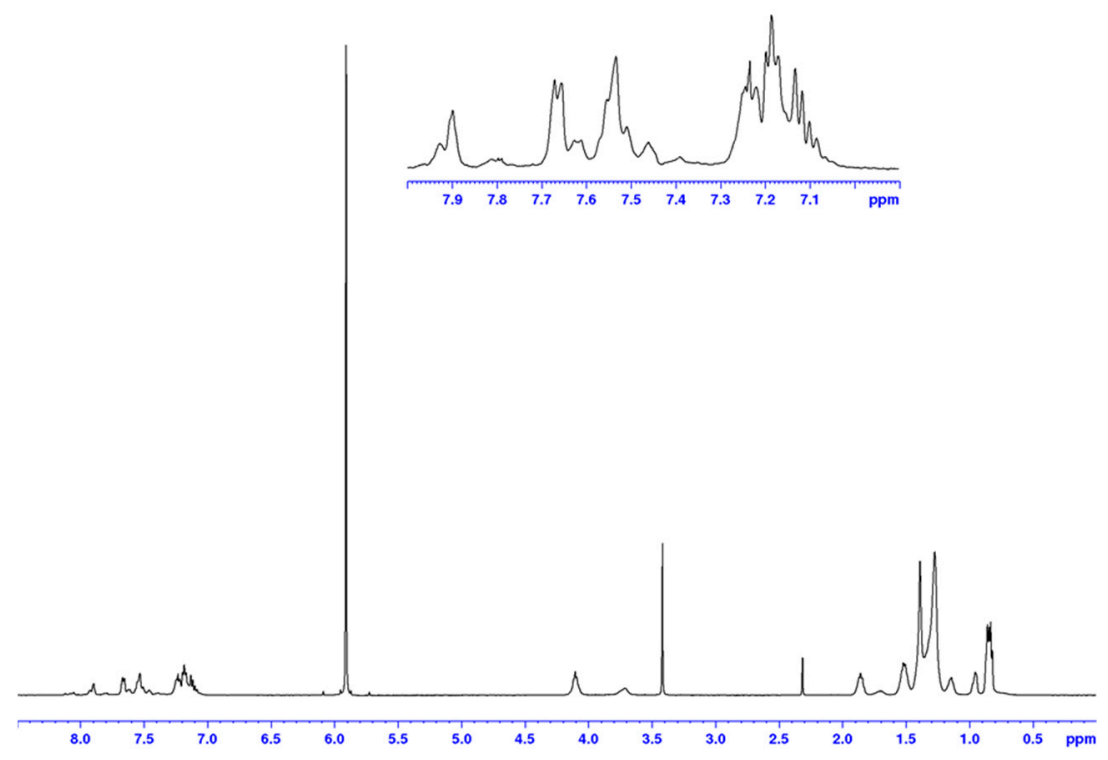

Figure 1. ${ }^{1} \mathrm{H}$ NMR spectrum of PPADTBTDI-DMO in $\mathrm{C}_{2} \mathrm{D}_{2} \mathrm{Cl}_{4}$ at $100{ }^{\circ} \mathrm{C}$.

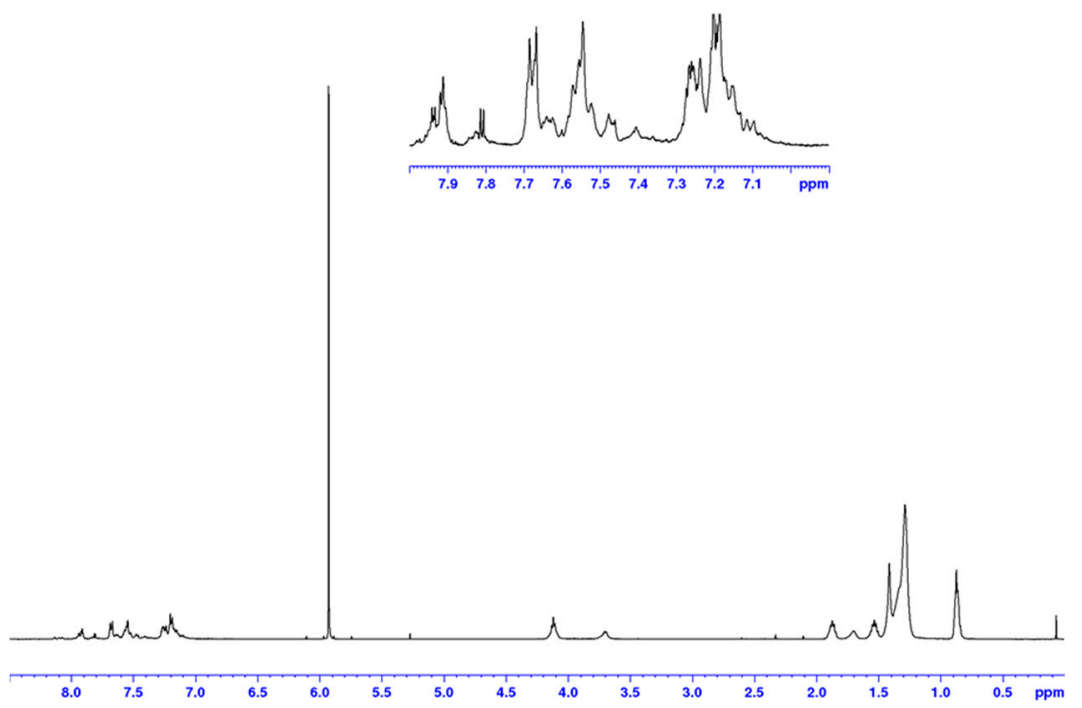

Figure 2. ${ }^{1} \mathrm{H}$ NMR spectrum of PPADTBTDI-8 in $\mathrm{C}_{2} \mathrm{D}_{2} \mathrm{Cl}_{4}$ at $100{ }^{\circ} \mathrm{C}$.

\section{Experimental Methodology}

\subsection{Materials}

Thiophene ( $\geq 99 \%), N$-bromosuccinimide (NBS) (99\%), N,N-dimethylformamide (DMF) ( $\geq 99 \%)$, dichloromethane (DCM) $(\geq 99.5 \%)$, 2-(tributylstannyl)thiophene $(97 \%)$, bis(triphenylphosphine)palladium(II) dichloride $\left[\mathrm{PdCl}_{2}\left(\mathrm{PPh}_{3}\right)_{2}\right](98 \%), \mathrm{N}$-thionylaniline (PhNSO) $(98 \%)$, chlorotrimethylsilane $\left[\left(\mathrm{CH}_{3}\right)_{3} \mathrm{SiCl}\right](\geq 98 \%)$, pyridine $(99.8 \%)$, xylene $(\geq 99 \%)$, triphenylphosphine $\left(\mathrm{Ph}_{3} \mathrm{P}\right)(99 \%)$, 3,7-dimethyl-1-octanol ( $\left.\geq 98 \%\right)$, potassium phthalimide $(98 \%)$, hydrazine hydrate (50-60\%), octylamine (99\%), palladium(II) acetate $\left[\mathrm{Pd}(\mathrm{OAc})_{2}\right](98 \%)$, anhydrous acetic anhydride $(\geq 99 \%)$, acetic acid $(\geq 99 \%)$ and tris $(o$-tolyl)phosphine $[\mathrm{P}(\mathrm{o}-$ tol) $)_{3}$ ] $(97 \%)$ were purchased from Sigma-Aldrich (Gillingham, UK). Anhydrous tin(II) chloride (98\%) and dimethyl acetylenedicarboxylate (98\%) were purchased from Alfa Aesar (Heysham, UK). All of the starting materials and reagents obtained from Sigma-Aldrich and Alfa Aesar were utilized without further purification. The majority of the reactions were carried out under argon atmosphere. Anhydrous solvents used for the reactions obtained from Grubbs solvent purification system within the Sheffield University/Chemistry depart- 
ment. 9,10-Bis(4-(dodecyloxy)phenyl)-2,6-bis(4,4,5,5-tetramethyl-1,3,2-dioxaborolan-2-yl) anthracene (M3) [21] was prepared according to literature procedure.

\subsection{Measurements}

${ }^{1} \mathrm{H}$ and ${ }^{13} \mathrm{C}$ nuclear magnetic resonance (NMR) spectra for the monomers measured either with a Bruker Avance AV 3HD 400 (400 MHz) spectrometer (Bruker, Berlin, Germany) in deuterated chloroform $\left(\mathrm{CDCl}_{3}\right)$, deuterated acetone $\left(\mathrm{CD}_{3} \mathrm{COCD}_{3}\right)$ or deuterated dimethyl sulfoxide $\left(\mathrm{CD}_{3} \mathrm{SOCD}_{3}\right)$ as solvents at room temperature. The ${ }^{1} \mathrm{H}$ NMR spectra for the polymers were measured with Bruker AV 3HD 500 (Bruker, Coventry, United Kingdom) $(500 \mathrm{MHz})$ in deuterated 1,1,2,2-tetrachloroethane $\left(\mathrm{C}_{2} \mathrm{D}_{2} \mathrm{Cl}_{4}\right)$ as the solvent at $100{ }^{\circ} \mathrm{C}$. The chemical shifts were measured in parts per million ( $\mathrm{ppm}$ ) relative to tetramethylsilane $\left(\delta_{\mathrm{H}} 0.00\right)$. The coupling constants $(J)$ are calculated in Hertz $(\mathrm{Hz})$. The ${ }^{1} \mathrm{H}$ and ${ }^{13} \mathrm{C}$ NMR spectra were analysed using Bruker TopSpin 3.2 software. Carbon, hydrogen, nitrogen and sulphur elemental analysis was performed by either the Perkin Elmer 2400 CHNS/O Series II Elemental Analyser (Perkin Elmer, Buckinghamshire, United Kingdom) or Vario MICRO Cube CHN/S Elemental Analyser for carbon, hydrogen, and nitrogen (CHN) analysis. Halides analysis (Br, F, and I) was performed by the Schöniger oxygen flask combustion method. Mass spectra for the monomers were recorded on Agilent 7200 accurate mass Q-TOF GC-MS spectrometer (Agilent, Santa Clara, CA, USA). Helium is used as a carrier gas in rate of $\left(1.2 \mathrm{~mL} \mathrm{~min}^{-1}\right)$, the injection volume is $(1.0 \mu \mathrm{L})$ and the concentration of the measured sample is $\left(5 \mathrm{mg} \mathrm{mL}^{-1}\right)$ in the $\mathrm{CHCl}_{3}$ solvent. The temperature program is between 60 and $320^{\circ} \mathrm{C}$ at $10{ }^{\circ} \mathrm{C} \mathrm{min}-1$. Mass spectra for the monomers were obtained by the electron ionization method (EI). Gel permeation chromatography (GPC) measurements accomplished by Viscotek GPC Max, a waters 410 instrument with a differential refractive index detector, two Polymer Labs PLgel $5 \mu$ Mixed C $(7.5 \times 300 \mathrm{~mm})$ columns and a guard $(7.5 \times 50 \mathrm{~mm})$. Molecular weights for the polymers were determined by preparing polymer solutions $\left(2.5 \mathrm{mg} \mathrm{mL}^{-1}\right)$ using chloroform (HPLC grade). The columns were thermostated at $40{ }^{\circ} \mathrm{C}$ using $\mathrm{CHCl}_{3}$. GPC curves were calibrated using a series of narrow polystyrene standards (Polymer Laboratories). Ultraviolet-visible (UV-vis) absorption spectra were measured by SPECORD 5600 Double Beam UV/visible Spectrophotometer (Hitachi, Berkshire, United Kingdom) at room temperature. The absorbance of the polymers was measured in $\mathrm{CHCl}_{3}$ solution using quartz cuvettes (light path length $=10 \mathrm{~mm}$ ) and blank quartz cuvettes including $\mathrm{CHCl}_{3}$ was used as a reference. The polymers were coated on quartz substrates from $\mathrm{CHCl}_{3}$ solutions $\left(1 \mathrm{mg} \mathrm{mL}^{-1}\right)$ and blank quartz substrate was used as a reference. Thermogravimetric analysis (TGA) measurements were recorded by Perkin Elmer (Pyris 1) Thermogravimetric Analyser (Perkin Elmer, Buckinghamshire, United Kingdom) at a scan rate of $10{ }^{\circ} \mathrm{C} \mathrm{min}^{-1}$ under an inert nitrogen atmosphere. Platinum pans were used as the sample holder and the weight of the measured samples was about (3 mg). XRD for the polymers was measured by Bruker D8 ADVANCE X-ray powder diffractometer with a $\mathrm{CuK} \alpha$ radiation source $(0.15418 \mathrm{~nm}$, rated as $1.6 \mathrm{~kW})$. The scanning angle was conducted over the range $2^{\circ}-40^{\circ}$. Cyclic voltammograms were recorded using a Princeton Applied Research Model 263A Potentiostat/Galvanostat (Princeton Applied Research, Cambridge, United Kingdom). A three-electrode system was used containing a Pt disc (area $=3.14 \times 10^{-2} \mathrm{~cm}^{2}$ ), platinum wire and $\mathrm{Ag} / \mathrm{Ag}^{+}$as the working electrode, counter electrode and reference electrode, respectively, in tetrabutylammonium perchlorate $\left(\mathrm{Bu}_{4} \mathrm{NClO}_{4}\right)$ acetonitrile solution $\left(0.1 \mathrm{~mol} \mathrm{dm}^{-3}\right)$. Measurements were conducted on polymer films that were prepared by drop casting $1.0 \mathrm{~mm}^{3}$ of polymer solution $\left(1 \mathrm{mg} \mathrm{cm}{ }^{-2}\right.$ in chloroform (HPLC grade)). Infrared absorption spectra were recorded on ATR Perkin Elmer Rx/FT-IR system and Nicolet Model 205 FT-IR spectrometer.

\subsection{Monomers and Polymers Synthesis}

2.3.1. Synthesis of 2,5-dibromothiophene (1)

The following is a modified procedure of previously reported by Ponomarenko et al. [24]. Thiophene (25.00 g, $297.12 \mathrm{mmol})$ in $N, N$-dimethylformamide (DMF) $(250 \mathrm{~mL})$ was added 
to a flask and cooled to $-15{ }^{\circ} \mathrm{C}$. To this solution, $\mathrm{N}$-bromosuccinimide (NBS) (110.00 g, $618.04 \mathrm{mmol})$ in DMF (300 $\mathrm{mL})$ was added dropwise in the dark and the reaction was stirred overnight at RT. The reaction contents were put into ice and dichloromethane (DCM) and subsequently extracted with DCM and the organic phase was washed with deionized $\mathrm{H}_{2} \mathrm{O}$ to a neutral $\mathrm{pH}$. The organic layer was collected and dried over $\mathrm{MgSO}_{4}$ and the solvent was concentrated to afford the product which was purified by vacuum distillation and obtained material 1 as a yellow oil $\left(59.30 \mathrm{~g}, 245 \mathrm{mmol}, 82 \%\right.$ yield). ${ }^{1} \mathrm{H} \mathrm{NMR}\left(\mathrm{CDCl}_{3}, \delta\right)$ : $6.87(\mathrm{~s}, 2 \mathrm{H}) .{ }^{13} \mathrm{C} \mathrm{NMR}\left(\mathrm{CDCl}_{3}, \delta\right): 130.4,111.6$. FT-IR $\left(\mathrm{cm}^{-1}\right): 3096,1726,1516,1410,1200$. EI-MS (m/z): $242[\mathrm{M}]^{+}$. Elemental analysis (\%) calculated for $\mathrm{C}_{4} \mathrm{H}_{2} \mathrm{Br}_{2} \mathrm{~S}: \mathrm{C}, 19.86 ; \mathrm{H}, 0.83$; Br, 66.06, S, 13.25. Found: C, 20.01; H, 0.85; Br, 65.02, S, 11.96 .

\subsubsection{Synthesis of 2,5-dibromo-3,4-dinitrothiophene (2)}

Material 2 was prepared according to the modified procedure as reported by Wen and Rasmussen [25]. Concentrated $\mathrm{H}_{2} \mathrm{SO}_{4}(150 \mathrm{~mL})$ and fuming $\mathrm{H}_{2} \mathrm{SO}_{4}(150 \mathrm{~mL}, 20 \%$ free $\left.\mathrm{SO}_{3}\right)$ were combined in a flask. This flask was cooled to $0{ }^{\circ} \mathrm{C}$ and material $1(26.00 \mathrm{~g}$, $107.46 \mathrm{mmol})$ was added dropwise. Concentrated nitric acid $(125 \mathrm{~mL})$ was added dropwise and the reaction contents were kept under $20^{\circ} \mathrm{C}$. During the addition of nitric acid, yellow precipitate formed quickly. The mixture was stirred for $3 \mathrm{~h}$ at $20-30^{\circ} \mathrm{C}$. Then, the mixture was poured into an ice and upon the melting of the ice, a yellow precipitate was filtrated and washed thoroughly with deionized $\mathrm{H}_{2} \mathrm{O}$. The product recrystallized from methanol

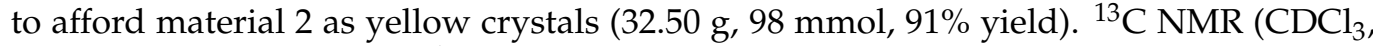

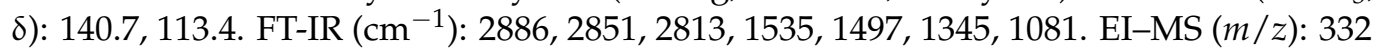
$[\mathrm{M}]^{+}$. Elemental analysis (\%) calculated for $\mathrm{C}_{4} \mathrm{Br}_{2} \mathrm{~N}_{2} \mathrm{O}_{4} \mathrm{~S}: \mathrm{C}, 14.47 ; \mathrm{N}, 8.44 ; \mathrm{S}, 9.66 ; \mathrm{Br}, 48.15$. Found: C, $14.51 ; \mathrm{N}, 7.91 ; \mathrm{S}, 9.19 ; \mathrm{Br}, 46.57$.

\subsubsection{Synthesis of $3^{\prime}, 4^{\prime}$-dinitro-2, $2^{\prime}: 5^{\prime}, 2^{\prime \prime}$-terthiophene (3)}

Material 3 was prepared according to the modified established procedure as documented by Schwiderski and Rasmussen [28]. In a flask, material 2 (9.90 g, $29.82 \mathrm{mmol}), 2-$ (tributylstannyl)thiophene (27.82 g, $74.54 \mathrm{mmol}$ ) and bis(triphenylphosphine)palladium(II) dichloride $\left[\mathrm{PdCl}_{2}\left(\mathrm{PPh}_{3}\right)_{2}\right](0.45 \mathrm{~g}, 0.64 \mathrm{mmol})$ were added. The system degassed under argon and anhydrous toluene $(100 \mathrm{~mL})$ was added and heated at $115^{\circ} \mathrm{C}$ for $24 \mathrm{~h}$. The flask cooled to RT and the volatiles were removed to obtain the product which was purified by column chromatography with the gradient (petroleum ether, $0-50 \%$ DCM) to obtain an orange solid and the product was further purified by recrystallization from methanol to obtain material 3 as orange crystals $\left(9.10 \mathrm{~g}, 27 \mathrm{mmol}, 90 \%\right.$ yield). ${ }^{1} \mathrm{H} \mathrm{NMR}\left(\mathrm{CDCl}_{3}, \delta\right): 7.62$ $(\mathrm{dd}, 2 \mathrm{H}, \mathrm{J}=1.0 \mathrm{~Hz}, 5.0 \mathrm{~Hz}), 7.56(\mathrm{dd}, 2 \mathrm{H}, \mathrm{J}=1.0 \mathrm{~Hz}, 4.0 \mathrm{~Hz}), 7.19(\mathrm{dd}, 2 \mathrm{H}, \mathrm{J}=4.0 \mathrm{~Hz}, 5.0 \mathrm{~Hz})$ ${ }^{13} \mathrm{C}$ NMR $\left(\mathrm{CDCl}_{3}, 8\right): 135.9,133.9,131.3,131.2,128.4,128.0$. FT-IR $\left(\mathrm{cm}^{-1}\right)$ : 3076, 1821, 1528, $1379,1348,1299,1223,1066$. EI-MS $(\mathrm{m} / \mathrm{z}): 338[\mathrm{M}]^{+}$. Elemental analysis (\%) calculated for $\mathrm{C}_{12} \mathrm{H}_{6} \mathrm{~N}_{2} \mathrm{O}_{4} \mathrm{~S}_{3}: \mathrm{C}, 42.60 ; \mathrm{H}, 1.79 ; \mathrm{N}, 8.28 ; \mathrm{S}, 28.42$. Found: $\mathrm{C}, 42.49 ; \mathrm{H}, 1.66 ; \mathrm{N}, 8.13 ; \mathrm{S}, 28.16$.

\subsubsection{Synthesis of $3^{\prime}, 4^{\prime}$-diamino-2, $2^{\prime}: 5,2^{\prime \prime}$-terthiophene (4)}

Material 4 was prepared according to the modified procedure as reported by Hailu et al. [29] $\mathrm{EtOH}(31 \mathrm{~mL})$ and $\mathrm{HCl}(62 \mathrm{~mL}, 35 \%)$ were added to material $3(3.00 \mathrm{~g}, 8.86 \mathrm{mmol})$ in a flask. To this mixture, anhydrous tin(II) chloride $(31.00 \mathrm{~g}, 163.50 \mathrm{mmol})$ in ethanol $(62 \mathrm{~mL})$ was added and stirred at $30^{\circ} \mathrm{C}$ for $24 \mathrm{~h}$. The mixture was cooled to RT and put into cold $\mathrm{NaOH}$. To this mixture, toluene was added and then stirred vigorously and filtered through celite. The product extracted with toluene and the organic phases was washed with $\mathrm{NaCl}$ and subsequently dried over $\mathrm{MgSO}_{4}$. The solvent was concentrated to obtain material 4 as a brown solid (2.40 g, $9 \mathrm{mmol}, 97 \%$ yield). ${ }^{1} \mathrm{H} \mathrm{NMR}\left(\mathrm{CDCl}_{3}, \delta\right): 7.30(\mathrm{~d}, 2 \mathrm{H}, \mathrm{J}=2.0 \mathrm{~Hz})$, $7.27(\mathrm{~s}, 2 \mathrm{H}), 7.09-7.14(\mathrm{~m}, 2 \mathrm{H}), 3.76$ (bs, 4H). ${ }^{13} \mathrm{C} \mathrm{NMR}\left(\mathrm{CDCl}_{3}, \delta\right): 136.0,133.6,127.8,124.0$, 124.0, 110.1. FT-IR $\left(\mathrm{cm}^{-1}\right)$ : 3371, 3298, 3224, 3182, 3096, 1631, 1615, 1573, 1528, 1509, 1441, 1336, 1294, 1070. EI-MS (m/z): $278[\mathrm{M}]^{+}$. Elemental analysis (\%) calculated for $\mathrm{C}_{12} \mathrm{H}_{10} \mathrm{~N}_{2} \mathrm{~S}_{3}$ : C, 51.77; H, 3.62; N, 10.06; S, 34.55. Found: C, 51.69; H, 3.54; N, 9.97; S, 34.78. 


\subsubsection{Synthesis of 4,6-bis(2-thienyl)-thieno[3,4-c][1,2,5]-thiadiazole (5)}

Material 5 was prepared according to the modified established procedure as reported by Delgado et al. [30]. Material $4(1.67 \mathrm{~g}, 5.99 \mathrm{mmol})$ was dissolved in dry pyridine $(30 \mathrm{~mL})$ in a flask and degassed under argon. To this mixture, $\mathrm{N}$-thionylaniline $(1.60 \mathrm{~g}$, $11.49 \mathrm{mmol}$ ) was added dropwise and chlorotrimethylsilane $(4.50 \mathrm{~g}, 41.42 \mathrm{mmol})$ was then added dropwise, resulting in a dark blue colour. The reaction contents were stirred for $3 \mathrm{~h}$ at $\mathrm{RT}$ and then put into DCM. The solution was washed with $\mathrm{HCl}$ and with deionized water and extracted with DCM. The organic phase dried over anhydrous $\mathrm{MgSO}_{4}$ and was subsequently filtered. The solvent evaporated to otain the product which was purified via chromatography with DCM to produce material 5 as blue crystals $(1.72 \mathrm{~g}, 6 \mathrm{mmol}$, $93 \%$ yield). ${ }^{1} \mathrm{H}$ NMR $\left(\mathrm{CDCl}_{3}, \delta\right): 7.59(\mathrm{dd}, 2 \mathrm{H}, \mathrm{J}=1.0 \mathrm{~Hz}, 3.5 \mathrm{~Hz}), 7.34(\mathrm{dd}, 2 \mathrm{H}, \mathrm{J}=1.0 \mathrm{~Hz}$, $5.0 \mathrm{~Hz}), 7.12(\mathrm{dd}, 2 \mathrm{H}, \mathrm{J}=3.5 \mathrm{~Hz}, 5.0 \mathrm{~Hz}) .13 \mathrm{C} \mathrm{NMR}\left(\mathrm{CDCl}_{3}, \delta\right): 156.3,135.0,128.2,125.4$, 124.3, 112.4. FT-IR ( $\left.\mathrm{cm}^{-1}\right)$ : 3102, 3073, 1797, 1525, 1483, 1365, 1223, 1137, 1047. EI-MS $(\mathrm{m} / \mathrm{z})$ : $306[\mathrm{M}]^{+}$. Elemental analysis (\%) calculated for $\mathrm{C}_{12} \mathrm{H}_{6} \mathrm{~N}_{2} \mathrm{~S}_{4}: \mathrm{C}, 47.04 ; \mathrm{H}, 1.97 ; \mathrm{N}, 9.14 ; \mathrm{S}$, 41.85. Found: C, 47.25; H, 2.18; N, 8.83; S, 39.16.

\subsubsection{Synthesis of 4,7-di(thien-2-yl)-2,1,3-benzothiadiazole-5,6-dimethyl ester (6)}

Material 6 was prepared according to the modified procedure as documented by Wang et al. [31]. Material $5(1.86 \mathrm{~g}, 6.06 \mathrm{mmol})$ and dimethyl acetylenedicarboxylate (1.73 g, $12.17 \mathrm{mmol}$ ) were combined in a flask. The system was evacuated and refilled with argon for three cycles before anhydrous xylene $(40 \mathrm{~mL})$ was added. The reaction contents were refluxed for $24 \mathrm{~h}$. The flask cooled to RT and the solvent was removed to afford the product which was purified by column chromatography with gradient (petroleum ether, $0-50 \%$ $\mathrm{DCM})$ to obtain material 6 as yellow crystals $\left(2.37 \mathrm{~g}, 6 \mathrm{mmol}, 94 \%\right.$ yield). ${ }^{1} \mathrm{H}$ NMR $\left(\mathrm{CDCl}_{3}\right.$, 8): $7.62(\mathrm{dd}, 2 \mathrm{H}, \mathrm{J}=1.0 \mathrm{~Hz}, 5.0 \mathrm{~Hz}), 7.44(\mathrm{dd}, 2 \mathrm{H}, \mathrm{J}=1.0 \mathrm{~Hz}, 3.5 \mathrm{~Hz}), 7.22(\mathrm{dd}, 2 \mathrm{H}, \mathrm{J}=3.5 \mathrm{~Hz}$, $5.0 \mathrm{~Hz}), 3.78(\mathrm{~s}, 6 \mathrm{H}) .{ }^{13} \mathrm{C} \mathrm{NMR}\left(\mathrm{CDCl}_{3}, 8\right): 168.1,153.6,135.1,132.0,129.7,129.0,127.3,126.2$, 53.1. FT-IR $\left(\mathrm{cm}^{-1}\right)$ : 3109, 2975, 2932, 2900, 2865, 2159, 2031, 1971, 1730, 1513, 1460, 1318, 1283, 1198. EI-MS $(m / z): 416[\mathrm{M}]^{+}$. Elemental analysis (\%) calculated for $\mathrm{C}_{18} \mathrm{H}_{12} \mathrm{~N}_{2} \mathrm{O}_{4} \mathrm{~S}_{3}$ : C, 51.91; H, 2.90; N, 6.73; S, 23.09. Found: C, 51.86; H, 2.94; N, 6.61; S, 22.97.

\subsubsection{Synthesis of 4,7-di(thien-2-yl)-2,1,3-benzothiadiazole-5,6-dicarboxylic acid (7)}

Material 7 was prepared according to the modified established procedure as reported by Nielsen et al. [32]. Sodium hydroxide $(4.00 \mathrm{~g}, 100.00 \mathrm{mmol})$ dissolved in deionized water $(30 \mathrm{~mL})$ and added to a flask. To this solution, ethanol $(200 \mathrm{~mL})$ and material $6(2.27 \mathrm{~g}$, $5.45 \mathrm{mmol}$ ) were added and the reaction contents were refluxed for $24 \mathrm{~h}$. The flask cooled to RT and deionized $\mathrm{H}_{2} \mathrm{O}$ was added. This mixture cooled to $0{ }^{\circ} \mathrm{C}$ and was neutralized by $\mathrm{HCl}$ to precipitate the product. The precipitate was filtered and subsequently washed with deionized $\mathrm{H}_{2} \mathrm{O}$. The precipitate dried under high vacuum to obtain material 7 as a yellow solid ( $1.80 \mathrm{~g}, 5 \mathrm{mmol}, 85 \%$ yield). ${ }^{1} \mathrm{H}$ NMR $\left(\mathrm{CD}_{3} \mathrm{SOCD}_{3}, \delta\right): 7.86(\mathrm{dd}, 2 \mathrm{H}, \mathrm{J}=1.0 \mathrm{~Hz}, 5.0 \mathrm{~Hz})$, $7.47(\mathrm{dd}, 2 \mathrm{H}, \mathrm{J}=1.0 \mathrm{~Hz}, 3.5 \mathrm{~Hz}), 7.25(\mathrm{dd}, 2 \mathrm{H}, \mathrm{J}=3.5 \mathrm{~Hz}, 5.0 \mathrm{~Hz}) .{ }^{13} \mathrm{C} \mathrm{NMR}\left(\mathrm{CD}_{3} \mathrm{SOCD}_{3}, \delta\right)$ : 168.4, 152.5, 134.8, 133.0, 129.7, 129.3, 127.2, 123.8. FT-IR $\left(\mathrm{cm}^{-1}\right)$ : 3106, broad (3300-2600), 2162, 2024, 1971, 1815, 1765, 1705, 1552, 1453, 1386, 1261, 1152, 1020. EI-MS ( $m / z): 387$ [M $-\mathrm{H}]^{+}$. Elemental analysis (\%) calculated for $\mathrm{C}_{16} \mathrm{H}_{8} \mathrm{~N}_{2} \mathrm{O}_{4} \mathrm{~S}_{3}: \mathrm{C}, 49.48 ; \mathrm{H}, 2.08 ; \mathrm{N}, 7.21 ; \mathrm{S}$, 24.76. Found: C, 45.33; H, 2.70; N, 6.47; S, 21.35.

\subsubsection{Synthesis of 4,7-di(thien-2-yl)-2,1,3-benzothiadiazole-5,6-dicarboxylic anhydride (8)}

Material 8 was prepared according to the modified procedure as documented by Lan et al. [33]. Material $7(1.15 \mathrm{~g}, 2.96 \mathrm{mmol})$ and anhydrous acetic anhydride (10.00 g, $97.95 \mathrm{mmol}$ ) were combined in a flask. The system was evacuated and refilled with argon for three cycles before anhydrous xylene $(30 \mathrm{~mL})$ was added. The mixture was heated at $130{ }^{\circ} \mathrm{C}$ for $6 \mathrm{~h}$. The mixture cooled to RT, and the solvent evaporated to obtain material 8 as red solid (1.06 g, $3 \mathrm{mmol}, 97 \%$ yield). ${ }^{1} \mathrm{H}$ NMR $\left(\mathrm{CDCl}_{3}, 8\right): 8.11(\mathrm{dd}, 2 \mathrm{H}, \mathrm{J}=1.0 \mathrm{~Hz}, 4.0 \mathrm{~Hz})$, $7.82(\mathrm{dd}, 2 \mathrm{H}, \mathrm{J}=1.0 \mathrm{~Hz}, 5.0 \mathrm{~Hz}), 7.33(\mathrm{dd}, 2 \mathrm{H}, \mathrm{J}=4.0 \mathrm{~Hz}, 5.0 \mathrm{~Hz}) .{ }^{13} \mathrm{C} \mathrm{NMR}\left(\mathrm{CD}_{3} \mathrm{SOCD}_{3}\right.$,

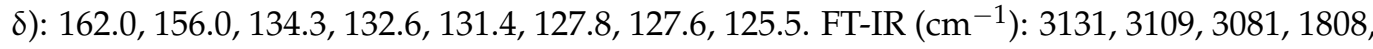


1765, 1552, 1453, 1393, 1247, 1152, 1088. EI-MS (m/z): $370[\mathrm{M}]^{+}$. Elemental analysis (\%) calculated for $\mathrm{C}_{16} \mathrm{H}_{6} \mathrm{~N}_{2} \mathrm{O}_{3} \mathrm{~S}_{3}: \mathrm{C}, 51.88 ; \mathrm{H}, 1.63 ; \mathrm{N}, 7.56 ; \mathrm{S}, 25.97$. Found: $\mathrm{C}, 52.11 ; \mathrm{H}, 2.00 ; \mathrm{N}$, 7.20; S, 24.55.

\subsubsection{Synthesis of 3,7-dimethyloctyl bromide (9)}

Material 9 was prepared according to the modified procedure as indicated by Matsueda et al. [34]. Triphenylphosphine $(21.10 \mathrm{~g}, 80.44 \mathrm{mmol})$ was added to a mixture of 3,7-dimethyl-1-octanol (12.61 g, $79.69 \mathrm{mmol})$ and dichloromethane $(250 \mathrm{~mL})$ and stirred in a flask. To this mixture, NBS $(14.26 \mathrm{~g}, 80.14 \mathrm{mmol})$ was added portionwise and stirred at RT for $90 \mathrm{~min}$. The mixture was washed with $\mathrm{NaHCO}_{3}$ solution, dried over $\mathrm{MgSO}_{4}$, filtered and the solvent was evaporated. The substance was stirred in petroleum ether for $1 \mathrm{~h}$ at RT, filtered and the filtrate evaporated. The product was purified by chromatography with petroleum ether to yield material 9 as colourless oil (23.00 g, $59 \mathrm{mmol}, 73 \%$ yield $)$. ${ }^{1} \mathrm{H} \mathrm{NMR}\left(\mathrm{CDCl}_{3}, \delta\right): 3.55-3.37(\mathrm{~m}, 2 \mathrm{H}), 1.96-1.83(\mathrm{~m}, 1 \mathrm{H}), 1.77-1.61(\mathrm{~m}, 2 \mathrm{H}), 1.60-1.49(\mathrm{~m}$, 1H), $1.41-1.24(\mathrm{~m}, 3 \mathrm{H}), 1.22-1.11(\mathrm{~m}, 3 \mathrm{H}), 0.82-0.94(\mathrm{~m}, 9 \mathrm{H}) .{ }^{13} \mathrm{C} \mathrm{NMR}\left(\mathrm{CDCl}_{3}, \delta\right): 40.1,39.2$, 36.7, 32.3, 31.7, 28.0, 24.6, 22.7, 22.6, 19.0. FT-IR (cm $\left.{ }^{-1}\right):$ 2953, 2925, 2868, 1464, 1382, 1261, 1173. EI-MS (m/z): $222.1[\mathrm{M}]^{+}$. Elemental analysis (\%) calculated for $\mathrm{C}_{10} \mathrm{H}_{21} \mathrm{Br}: \mathrm{C}, 54.30 ; \mathrm{H}$, 9.57; $\mathrm{Br}, 36.13$. Found: $\mathrm{C}, 55.04 ; \mathrm{H}, 9.53 ; \mathrm{Br}, 34.23$.

\subsubsection{Synthesis of N-(3,7-dimethyloctyl) phthalimide (10)}

Material 10 was prepared according to the modified procedure as reported by Thomson et al. [35]. Material 9 (4.07 g, $18.40 \mathrm{mmol})$ and anhydrous DMF (20 mL) were added in a flask. To this mixture, potassium phthalimide $(3.75 \mathrm{~g}, 20.27 \mathrm{mmol})$ was added and the reaction contents were heated to $90^{\circ} \mathrm{C}$ for $17 \mathrm{~h}$. The mixture was cooled to RT and put in deionized $\mathrm{H}_{2} \mathrm{O}$ and the product was subsequently extracted with DCM. The organic extracts combined, washed with $\mathrm{KOH}$ and deionized water. The organic phase dried over $\mathrm{MgSO}_{4}$ and the solvent was evaporated to obtain the product which was purified via chromatography with dichloromethane to yield material 10 as a colourless oil (5.29 $\mathrm{g}$, $18 \mathrm{mmol}, 91 \%$ yield). ${ }^{1} \mathrm{H} \mathrm{NMR}\left(\mathrm{CDCl}_{3}, \delta\right): 7.85(\mathrm{dd}, 2 \mathrm{H}, \mathrm{J}=3.0 \mathrm{~Hz}, 5.5 \mathrm{~Hz}), 7.72(\mathrm{dd}, 2 \mathrm{H}$, $\mathrm{J}=3.0 \mathrm{~Hz}, 5.5 \mathrm{~Hz}), 3.80-3.66(\mathrm{~m}, 2 \mathrm{H}), 1.77-1.66(\mathrm{~m}, 1 \mathrm{H}), 1.53-1.43(\mathrm{~m}, 3 \mathrm{H}), 1.41-1.25(\mathrm{~m}$, $3 \mathrm{H}), 1.20-1.11(\mathrm{~m}, 3 \mathrm{H}), 0.98(\mathrm{~d}, 3 \mathrm{H}, \mathrm{J}=6.5 \mathrm{~Hz}), 0.87(\mathrm{~d}, 6 \mathrm{H}, \mathrm{J}=7.0 \mathrm{~Hz}) .{ }^{13} \mathrm{C} \mathrm{NMR}\left(\mathrm{CDCl}_{3}, \delta\right)$ : 168.4, 133.8, 132.2, 123.1, 39.2, 37.0, 36.3, 35.5, 30.7, 27.9, 24.5, 22.7, 22.6, 19.4. FT-IR ( $\left.\mathrm{cm}^{-1}\right)$ : 2953, 2925, 2868, 1772, 1706, 1616, 1469, 1398, 1267, 1189, 1055. EI-MS (m/z): $288.2[\mathrm{MH}]^{+}$. Elemental analysis (\%) calculated for $\mathrm{C}_{18} \mathrm{H}_{25} \mathrm{NO}_{2}$ : C, 75.22; $\mathrm{H}, 8.77 ; \mathrm{N}, 4.87$. Found: $\mathrm{C}$, $72.17 ; \mathrm{H}, 8.62 ; \mathrm{N}, 4.43$.

\subsubsection{Synthesis of 3,7-dimethyl-1-octanamine (11)}

Material 11 was prepared according to the modified procedure as documented by Yue et al. [36]. Material 10 (6.03 g, $20.98 \mathrm{mmol})$, hydrazine hydrate $(4.0 \mathrm{~mL}, 65.0 \mathrm{mmol}$, $51 \%)$ and methanol $(100 \mathrm{~mL})$ were combined in a flask. The reaction contents refluxed until the starting material disappeared. Upon completion, excess $\mathrm{HCl}$ was added and the mixture was refluxed for $1 \mathrm{~h}$ and then cooled to RT. The precipitate was filtered and washed with water. The methanol was concentrated and the residue was diluted with dichloromethane. The organic layer was washed with $\mathrm{KOH}$ and the product was extracted with dichloromethane. The organic phase was washed with $\mathrm{NaCl}$, dried over $\mathrm{MgSO}_{4}$ and the solvent was concentrated to yield material 11 as a brown oil $(2.85 \mathrm{~g}, 18 \mathrm{mmol}$, 86\% yield). ${ }^{1} \mathrm{H}$ NMR $\left(\mathrm{CDCl}_{3}, \delta\right): 2.82-2.62(\mathrm{~m}, 2 \mathrm{H}), 1.60-1.43(\mathrm{~m}, 3 \mathrm{H}), 1.35-1.22(\mathrm{~m}, 4 \mathrm{H})$,

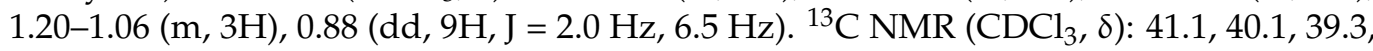
37.3, 30.5, 28.0, 24.7, 22.7, 22.6, 19.6. FT-IR $\left(\mathrm{cm}^{-1}\right): 3521,3375,3219,3021,2953,2925,2868$, 2155, 2028, 1978, 1598, 1464, 1382, 1166, 1063. EI-MS (m/z): 157.2 [M] $^{+}$. Elemental analysis (\%) calculated for $\mathrm{C}_{10} \mathrm{H}_{23} \mathrm{~N}$ : C, 76.36; H, 14.74; N, 8.90. Found: C, 71.74; H, 13.51; N, 7.71. 
2.3.12. Synthesis of 4,7-di(thien-2-yl)-2,1,3-benzothiadiazole-5,6-N-(3,7-dimethyloctyl)dicarboxylic imide (12)

Material 8 (1.00 g, $2.69 \mathrm{mmol})$, acetic acid $(50 \mathrm{~mL}, 100 \%)$ and material 11 (0.88 g, $5.59 \mathrm{mmol}$ ) were combined in a flask. The system was evacuated and refilled with argon for three cycles and heated at $110^{\circ} \mathrm{C}$ overnight. The mixture was cooled to RT, acetic anhydride $(20 \mathrm{~mL})$ was added and heated at $110^{\circ} \mathrm{C}$ for $6 \mathrm{~h}$. The mixture was cooled to RT and the solvent was concentrated to yield the product which was purified by chromatography with (60:10, petroleum ether: ethyl acetate) to afford material 12 as an orange solid (1.15 g, $2.3 \mathrm{mmol}, 84 \%$ yield $).{ }^{1} \mathrm{H}$ NMR $\left(\mathrm{CDCl}_{3}, \delta\right): 7.91(\mathrm{dd}, 2 \mathrm{H}, \mathrm{J}=1.0 \mathrm{~Hz}, 3.5 \mathrm{~Hz}), 7.73(\mathrm{dd}, 2 \mathrm{H}$, $\mathrm{J}=1.0 \mathrm{~Hz}, 5.0 \mathrm{~Hz}), 7.30(\mathrm{dd}, 2 \mathrm{H}, \mathrm{J}=3.5 \mathrm{~Hz}, 5.0 \mathrm{~Hz}), 3.84-3.70(\mathrm{~m}, 2 \mathrm{H}), 1.78-1.65(\mathrm{~m}, 1 \mathrm{H})$, 1.55-1.43 (m, 3H), 1.39-1.22 (m, 3H), 1.20-1.08 (m, 3H), 0.97 (d, 3H, J = 6.0 Hz), $0.86(\mathrm{~d}$, $6 \mathrm{H}, \mathrm{J}=6.0 \mathrm{~Hz}) .{ }^{13} \mathrm{C} \mathrm{NMR}\left(\mathrm{CDCl}_{3}, \delta\right): 165.7,156.5,133.1,131.5,130.2,127.0,126.9,126.7$, $39.2,37.2,37.0,35.2,31.0,27.9,24.6,22.7,22.6,19.4$. FT-IR $\left(\mathrm{cm}^{-1}\right): 3439,3102,3074,2953$, 2925, 2865, 1804, 1751, 1694, 1549, 1453, 1364, 1226, 1162, 1056. EI-MS (m/z): $510.1[\mathrm{MH}]^{+}$. Elemental analysis (\%) calculated for $\mathrm{C}_{26} \mathrm{H}_{27} \mathrm{~N}_{3} \mathrm{O}_{2} \mathrm{~S}_{3}: \mathrm{C}, 61.27 ; \mathrm{H}, 5.34 ; \mathrm{N}, 8.24 ; \mathrm{S}, 18.87$. Found: C, 61.59; H, 5.56; N, 7.94; S, 16.79.

2.3.13. Synthesis of 4,7-di(thien-2-yl)-2,1,3-benzothiadiazole-5,6- $N$-octyl-dicarboxylic imide (13)

Material 13 was prepared followed by the same procedure for the synthesis of material 12 except octylamine $(1.20 \mathrm{~g}, 9.28 \mathrm{mmol})$ was used. Material 13 was obtained as an orange solid (1.20 g, $2.5 \mathrm{mmol}, 93 \%$ yield). ${ }^{1} \mathrm{H} \mathrm{NMR}\left(\mathrm{CDCl}_{3}, \delta\right): 7.91$ (dd, 2H, J = $1.0 \mathrm{~Hz}, 3.5 \mathrm{~Hz}$ ), $7.73(\mathrm{dd}, 2 \mathrm{H}, \mathrm{J}=1.0 \mathrm{~Hz}, 5.0 \mathrm{~Hz}), 7.30(\mathrm{dd}, 2 \mathrm{H}, \mathrm{J}=3.5 \mathrm{~Hz}, 5.0 \mathrm{~Hz}), 3.74(\mathrm{t}, 2 \mathrm{H}, \mathrm{J}=7.5 \mathrm{~Hz})$, 1.65-1.76 (m, 2H), 1.23-1.41 (m, 10H), $0.88(\mathrm{t}, 3 \mathrm{H}, \mathrm{J}=7.0 \mathrm{~Hz}) .{ }^{13} \mathrm{C} \mathrm{NMR}\left(\mathrm{CDCl}_{3}, \delta\right): 165.8$, $156.5,133.1,131.5,130.2,127.1,126.9,126.7,39.0,31.8,29.1,28.2,27.0,22.7,14.0$. FT-IR $\left(\mathrm{cm}^{-1}\right):$ 3443, 3102, 3070, 2918, 2854, 1808, 1754, 1694, 1556, 1457, 1364, 1226, 1169, 1098. EI-MS $(m / z): 481.1[\mathrm{M}]^{+}$. Elemental analysis (\%) calculated for $\mathrm{C}_{24} \mathrm{H}_{23} \mathrm{~N}_{3} \mathrm{O}_{2} \mathrm{~S}_{3}: \mathrm{C}, 59.85 ; \mathrm{H}$, 4.81; N, 8.72; S, 19.97. Found: C, 59.91; H, 4.93; N, 8.70; S, 20.72.

2.3.14. Synthesis of 4,7-di(5-bromo-thien-2-yl)-2,1,3-benzothiadiazole-5,6- $N$-(3,7-dimethyloctyl)dicarboxylic imide (M1)

Material $12(1.00 \mathrm{~g}, 1.96 \mathrm{mmol})$ and THF $(100 \mathrm{~mL})$ were combined in a flask. To this mixture, NBS (1.74 g, $9.77 \mathrm{mmol})$ was added and stirred at RT overnight in the dark. The solvent evaporated to obtain the product as a red solid, and subsequently was washed with cold $\mathrm{CH}_{3} \mathrm{OH}$, filtered and dried. The product was purified via chromatography with DCM to yield $\mathrm{M} 1$ as a red solid $(1.28 \mathrm{~g}, 2 \mathrm{mmol}, 98 \%$ yield $) .{ }^{1} \mathrm{H} \mathrm{NMR}\left(\mathrm{CDCl}_{3}, \delta\right): 7.80(\mathrm{~d}$, $2 \mathrm{H}, \mathrm{J}=4.0 \mathrm{~Hz}), 7.24(\mathrm{~d}, 2 \mathrm{H}, \mathrm{J}=4.0 \mathrm{~Hz}), 3.70-3.84(\mathrm{~m}, 2 \mathrm{H}), 1.78-1.66(\mathrm{~m}, 1 \mathrm{H}), 1.54-1.44(\mathrm{~m}$, $3 \mathrm{H}), 1.41-1.22(\mathrm{~m}, 3 \mathrm{H}), 1.20-1.11(\mathrm{~m}, 3 \mathrm{H}), 0.98(\mathrm{~d}, 3 \mathrm{H}, \mathrm{J}=6.0 \mathrm{~Hz}), 0.87(\mathrm{~d}, 6 \mathrm{H}, \mathrm{J}=6.5 \mathrm{~Hz})$. ${ }^{13} \mathrm{C}$ NMR $\left(\mathrm{CDCl}_{3}, \delta\right): 165.6,155.9,134.1,133.0,129.8,126.4,125.8,118.7,39.2,37.3,37.0$, $35.2,31.0,27.9,24.6,22.7,22.6,19.4$. FT-IR ( $\left.\mathrm{cm}^{-1}\right): 3429,3120,2957,2918,2865,1747,1691$, 1563, 1460, 1364, 1283, 1073. EI-MS ( $\mathrm{m} / \mathrm{z}): 666.9$ [M] ${ }^{+}$. Elemental analysis (\%) calculated for $\mathrm{C}_{26} \mathrm{H}_{25} \mathrm{Br}_{2} \mathrm{~N}_{3} \mathrm{O}_{2} \mathrm{~S}_{3}$ : C, 46.78; H, 3.78; $\mathrm{Br}, 23.94 ; \mathrm{N}, 6.30 ; \mathrm{S}, 14.41$. Found: $\mathrm{C}, 46.61 ; \mathrm{H}, 3.61 ; \mathrm{Br}$, 23.95; N, 6.29; S, 14.64 .

2.3.15. Synthesis of 4,7-di(5-bromo-thien-2-yl)-2,1,3-benzothiadiazole-5,6-N-octyl-dicarboxylic imide (M2)

M2 was prepared followed by the same procedure for the synthesis of M1, where compound material $13(1.00 \mathrm{~g}, 2.07 \mathrm{mmol})$ was used with THF (100 mL) and NBS (1.84 g, $10.33 \mathrm{mmol})$. M2 was obtained as a red solid $(1.27 \mathrm{~g}, 2 \mathrm{mmol}, 96 \%$ yield $) .{ }^{1} \mathrm{H} \mathrm{NMR}\left(\mathrm{CDCl}_{3}\right.$, $\delta): 7.80(\mathrm{~d}, 2 \mathrm{H}, \mathrm{J}=4.0 \mathrm{~Hz}), 7.24(\mathrm{~d}, 2 \mathrm{H}, \mathrm{J}=4.0 \mathrm{~Hz}), 3.75(\mathrm{t}, 2 \mathrm{H}, \mathrm{J}=7.0 \mathrm{~Hz}),, 1.66-1.75(\mathrm{~m}$,

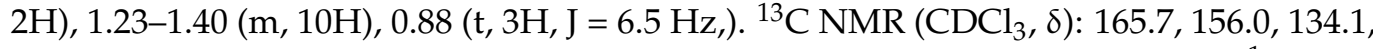
133.0, 129.8, 126.4, 125.9, 118.7, 39.0, 31.8, 29.1, 28.3, 27.0, 22.6, 14.1. FT-IR (cm $\left.{ }^{-1}\right): 3421$, 3120, 2953, 2911, 2850, 1744, 1687, 1556, 1446, 1375, 1244, 1176. EI-MS ( $m / z): 638.9$ [M] $]^{+}$ Elemental analysis (\%) calculated for $\mathrm{C}_{24} \mathrm{H}_{21} \mathrm{Br}_{2} \mathrm{~N}_{3} \mathrm{O}_{2} \mathrm{~S}_{3}: \mathrm{C}, 45.08 ; \mathrm{H}, 3.31 ; \mathrm{N}, 6.57 ; \mathrm{S}, 15.04$; $\mathrm{Br}$, 24.99. Found: C, 44.79; H, 3.41; N, 6.47; S, 15.74; Br, 28.80. 
2.3.16. Poly[9,10-bis(4-(dodecyloxy)phenyl)-2,6-anthracene-alt-5,5-(4',7'-bis(2-thienyl)$2^{\prime}, 1^{\prime}, 3^{\prime}$-benzothiadiazole-N-5,6-(3,7-dimethyloctyl)dicarboxylic imide)] (PPADTBTDI-DMO)

M1 (150 mg, $0.224 \mathrm{mmol})$ and M3 (213.6 $\mathrm{mg}, 0.224 \mathrm{mmol})$ were added to a flask and degassed under argon. Anhydrous THF $(10 \mathrm{~mL})$ followed by sodium hydrogen carbonate solution $(2.5 \mathrm{~mL}, 5 \% \mathrm{wt}$, degassed) were added and the system was degassed again. To this mixture, $\mathrm{Pd}(\mathrm{OAc})_{2}(3.7 \mathrm{mg}, 0.0168 \mathrm{mmol})$ and $\mathrm{P}(\mathrm{o} \text {-tol })_{3}(10.2 \mathrm{mg}, 0.0336 \mathrm{mmol})$ were added, degassed and heated at $90{ }^{\circ} \mathrm{C}$ for $23 \mathrm{~h}$. The flask cooled to RT, the polymer was dissolved in $\mathrm{CHCl}_{3}(200 \mathrm{~mL})$ and an $\mathrm{NH}_{4} \mathrm{OH}$ solution $\left(50 \mathrm{~mL}, 35 \%\right.$ in $\left.\mathrm{H}_{2} \mathrm{O}\right)$ was added and the mixture was stirred overnight. The organic phase was separated and washed with deionized $\mathrm{H}_{2} \mathrm{O}$. The organic phase was concentrated to around $(50 \mathrm{~mL})$ and put into methanol $(300 \mathrm{~mL})$ and stirred overnight. The mixture was filtered and the polymer was cleaned using Soxhlet extraction with methanol $(300 \mathrm{~mL})$, acetone $(300 \mathrm{~mL})$, hexane $(300 \mathrm{~mL})$ and then toluene $(300 \mathrm{~mL})$. The toluene fraction was concentrated to around $(50 \mathrm{~mL})$ and then put into methanol $(300 \mathrm{~mL})$. The mixture was stirred overnight and the pure polymer recovered by filtration to obtain PPADTBTDI-DMO as purple powders. Toluene fraction (82 $\mathrm{mg}$, $0.07 \mathrm{mmol}, 30 \%$ yield), chloroform fraction (180 $\mathrm{mg}, 0.15 \mathrm{mmol}, 67 \%$ yield) with total yield 97\%. GPC: toluene fraction, $M_{\mathrm{n}}=6700 \mathrm{~g} \mathrm{~mol}^{-1}, M_{\mathrm{w}}=12600 \mathrm{~g} \mathrm{~mol}^{-1}$, PDI $=1.8$ and Dp $=6$; chloroform fraction, $M_{\mathrm{n}}=12700 \mathrm{~g} \mathrm{~mol}^{-1}, M_{\mathrm{w}}=22400 \mathrm{~g} \mathrm{~mol}^{-1}$, PDI $=1.7$ and Dp $=11$. ${ }^{1} \mathrm{H}$ NMR (toluene fraction) $\left(\mathrm{C}_{2} \mathrm{D}_{2} \mathrm{Cl}_{4}, \delta\right): 7.96-7.87(\mathrm{bm}, 2 \mathrm{H}), 7.71-7.61(\mathrm{bm}, 2 \mathrm{H}), 7.57-7.50$ (bm, 4H), 7.30-7.05 (bm, 10H), 4.18-4.01 (bm, 4H), 3.81-3.61 (bm, 2H), 1.91-1.79 (bm, 4H), 1.78-1.64 (bm, 1H), 1.60-1.46 (bm, 8H), 1.43-1.21 (bm, 34H), 1.20-1.09 (bm, 3H), 1.00-0.90 (bm, 3H), 0.89-0.78 (bm, 12H). FT-IR ( $\left.\mathrm{cm}^{-1}\right)$ : 2918, 2850, 1754, 1701, 1606, 1570, 1428, 1361, $1240,1176,1066$. Elemental analysis (\%) calculated for $\mathrm{C}_{76} \mathrm{H}_{89} \mathrm{~N}_{3} \mathrm{O}_{4} \mathrm{~S}_{3}: \mathrm{C}, 75.77 ; \mathrm{H}, 7.45 ; \mathrm{N}$, 3.49; S, 7.98. Found: C, 73.30; H, 7.15; N, 3.27; S, 7.79.

2.3.17. Poly[9,10-bis(4-(dodecyloxy)phenyl)-2,6-anthracene-alt-5,5-(4',7'-bis(2-thienyl)$2^{\prime}, 1^{\prime}, 3^{\prime}$-benzothiadiazole-5,6-N-octyl-dicarboxylic imide)] (PPADTBTDI-8)

M2 (143.2 mg, $0.224 \mathrm{mmol})$ and M3 (213.6 mg, $0.224 \mathrm{mmol})$ were added to a flask and degassed under argon. Anhydrous THF $(10 \mathrm{~mL})$ followed by sodium hydrogen carbonate solution $(2.5 \mathrm{~mL}, 5 \% \mathrm{wt}$, degassed) were added and the system, which was degassed again. To this mixture, $\mathrm{Pd}(\mathrm{OAc})_{2}(3.7 \mathrm{mg}, 0.0168 \mathrm{mmol})$ and $\mathrm{P}(\mathrm{o} \text {-tol })_{3}(10.2 \mathrm{mg}, 0.0336 \mathrm{mmol})$ were added, degassed and heated at $90{ }^{\circ} \mathrm{C}$ for $24 \mathrm{~h}$. The flask was cooled to RT, the polymer was dissolved in $\mathrm{CHCl}_{3}(200 \mathrm{~mL})$ and an $\mathrm{NH}_{4} \mathrm{OH}$ solution $\left(50 \mathrm{~mL}, 35 \%\right.$ in $\left.\mathrm{H}_{2} \mathrm{O}\right)$ was added and the mixture stirred overnight. The organic phase was separated and washed with deionized $\mathrm{H}_{2} \mathrm{O}$. The organic phase concentrated to around $(50 \mathrm{~mL})$ and put into methanol $(300 \mathrm{~mL})$ and stirred overnight. The mixture filtered and the polymer cleaned using Soxhlet extraction with methanol $(300 \mathrm{~mL})$, acetone $(300 \mathrm{~mL})$, hexane $(300 \mathrm{~mL})$ and then toluene $(300 \mathrm{~mL})$. The toluene fraction was concentrated to around $(50 \mathrm{~mL})$ and was then put into methanol $(300 \mathrm{~mL})$. The mixture was stirred overnight and the pure polymer was recovered by filtration to afford PPADTBTDI- 8 as purple powders. Toluene fraction (65 $\mathrm{mg}$, $0.05 \mathrm{mmol}, 25 \%$ yield), chloroform fraction (190 $\mathrm{mg}, 0.16 \mathrm{mmol}, 72 \%$ yield) with total yield $97 \%$. GPC: toluene fraction, $M_{\mathrm{n}}=6000 \mathrm{~g} \mathrm{~mol}^{-1}, M_{\mathrm{W}}=11100 \mathrm{~g} \mathrm{~mol}^{-1}, \mathrm{PDI}=1.8$ and Dp $=5$; chloroform fraction, $M_{\mathrm{n}}=12500 \mathrm{~g} \mathrm{~mol}^{-1}, M_{\mathrm{w}}=27400 \mathrm{~g} \mathrm{~mol}^{-1}$, PDI $=2.1$ and Dp $=11$. ${ }^{1} \mathrm{H}$ NMR (toluene fraction) $\left(\mathrm{C}_{2} \mathrm{D}_{2} \mathrm{Cl}_{4}, \delta\right): 7.96-7.87(\mathrm{bm}, 2 \mathrm{H}), 7.71-7.61(\mathrm{bm}, 2 \mathrm{H}), 7.57-7.50$ (bm, 4H), 7.30-7.05 (bm, 10H), 4.18-4.01 (bm, 4H), 3.81-3.61 (bm, 2H), 1.91-1.79 (bm, 4H), 1.79-1.63 (bm, 2H), 1.60-1.48 (bm, 4H), 1.46-1.20 (bm, 42H), 0.92-0.79 (bm, 9H). FT-IR $\left(\mathrm{cm}^{-1}\right): 2921,2850,1751,1701,1606,1574,1432,1364,1244,1173,1031$. Elemental analysis (\%) calculated for $\mathrm{C}_{74} \mathrm{H}_{85} \mathrm{~N}_{3} \mathrm{O}_{4} \mathrm{~S}_{3}$ : C, 75.54; $\mathrm{H}, 7.28 ; \mathrm{N}, 3.57 ; \mathrm{S}, 8.17$. Found: C, 72.97; $\mathrm{H}$, 7.05; N, 3.38; S, 7.58. 


\section{Results and Discussion}

\subsection{Molecular Weights and Yield}

The molecular weights of the polymers were measured by gel permeation chromatography (GPC) in chloroform solution at $40{ }^{\circ} \mathrm{C}$ relative to polystyrene standards (Table 1). Both polymers were synthesised in good yields and the number average molecular weight $\left(M_{n}\right)$ of toluene and chloroform fractions are comparable. The $M_{n}$ for the toluene fractions of the polymers are relatively low. However, the $M_{n}$ for the chloroform fractions of the polymers are almost twice than those of the toluene fractions. The results indicate that anchoring different chains (n-octyl vs. 3,7-dimethyloctyl) on the imide functionality of the BTDI building blocks provides polymers with similar processability and has a negligible impact on the $M_{\mathrm{n}}$ values of the resulting polymers.

Table 1. The percentage yield, number and weight average molecular weights with polydispersity indexes of PPADTBTDIDMO and PPADTBTDI-8.

\begin{tabular}{|c|c|c|c|c|c|c|c|}
\hline \multirow[b]{2}{*}{ Polymer } & \multirow[b]{2}{*}{$\%$ Yield } & \multicolumn{3}{|c|}{ Toluene Fraction } & \multicolumn{3}{|c|}{ Chloroform Fraction } \\
\hline & & $\begin{array}{c}M_{\mathrm{n}} \\
\left(\mathrm{g} \mathrm{mol}^{-1}\right)\end{array}$ & $\begin{array}{c}M_{\mathrm{w}} \\
\left(\mathrm{g} \mathrm{mol}^{-1}\right)\end{array}$ & $\begin{array}{l}\text { Poly Dispersity } \\
\text { Index (PDI) }\end{array}$ & $\begin{array}{c}M_{\mathrm{n}} \\
\left(\mathrm{g} \mathrm{mol}^{-1}\right)\end{array}$ & $\begin{array}{c}M_{\mathrm{w}} \\
\left(\mathrm{g} \mathrm{mol}^{-1}\right)\end{array}$ & PDI \\
\hline PPADTBTDI-DMO & 97 & 6700 & 12,600 & 1.8 & 12,700 & 22,400 & 1.7 \\
\hline PPADTBTDI-8 & 97 & 6000 & 11,000 & 1.8 & 12,500 & 27,400 & 2.1 \\
\hline
\end{tabular}

\subsection{Optical Properties}

The normalized UV-vis absorption spectra of the polymers in chloroform solutions and in thin-films are shown in Figure 3. The optical properties of these polymers are summarized in Table 2. PPADTBTDI-DMO and PPADTBTDI-8 display absorption maxima at 540 and $535 \mathrm{~nm}$ in solutions with shoulder absorption bands at 632 and $635 \mathrm{~nm}$, respectively. The shoulder absorption bands may arise from $\pi-\pi$ intermolecular interactions between the polymer chains and their aggregation in solutions. As compared to chloroform solutions, the absorption maxima in film states are slightly red shifted $(5-11 \mathrm{~nm})$ with stronger shoulder absorption bands at $660 \mathrm{~nm}$ for both PPADTBTDI-DMO and PPADTBTDI-8. This result indicates that both polymers show more pronounced aggregation in the solid state with the formation of more coplanar structures in thin films. The $E_{g}$ of the polymers are assessed from the absorption onsets in thin films. Both polymers have comparable $\mathrm{E}_{\mathrm{g}}$ values of $1.66 \mathrm{eV}$. The UV-vis absorption spectra revealed that attaching different chains on the imide functionality of the BTDI units does not have substantial influence on the optical properties of the polymers.

Table 2. The UV-vis data and optical $\mathrm{E}_{\mathrm{g}}$ of the polymers.

\begin{tabular}{cccccc}
\hline \multirow{2}{*}{ Polymer } & \multirow{2}{\varepsilon}{} & Solution & \multicolumn{3}{c}{ Film } \\
\cline { 3 - 6 } & $\left.\mathbf{( M}^{-\mathbf{1}} \mathbf{c m}^{-\mathbf{1}}\right)$ & $\lambda_{\max }(\mathbf{n m})$ & $\lambda_{\max }(\mathbf{n m})$ & $\lambda_{\text {onset }}(\mathbf{n m})$ & $\mathbf{E}_{\mathbf{g}}(\mathbf{e V})$ \\
\hline PPADTBTDI-DMO & 24,300 & 540 & 545 & 744 & 1.66 \\
PPADTBTDI-8 & 34,000 & 535 & 546 & 744 & 1.66 \\
\hline
\end{tabular}

The absorption maxima and $\mathrm{E}_{\mathrm{g}}$ of PPADTBTDI-DMO and PPADTBTDI-8 are comparable with PTATDPP and PTAFDPP analogues [23]. The E $\mathrm{g}_{\mathrm{g}}$ of PPADTBTDI-DMO and PPADTBTDI-8 are significantly lower than those of their PPATBT, PPATBT- 8 and PPAT2BT8 counterparts [21]. This may arise from the stronger electron withdrawing capability of BTDI units than BT and $(\mathrm{OR})_{2} \mathrm{BT}$ moieties, consequently lowering the LUMO energy levels of BTDI-based polymers. The $\mathrm{E}_{\mathrm{g}}$ of PPADTBTDI-DMO and PPADTBTDI-8 are significantly lower than that of fluorene-, dibenzosilole and carbazole-based polymers [38,39]. This is probably due to anthracene-based two-dimensional conjugated polymers have stronger and broader absorption bands [40]. The absorption coefficient $(\varepsilon)$ of the PPADTBTDI- 8 is 
significantly higher than PPADTBTDI-DMO despite the fact that they have comparable $M_{n}$ values and $E_{g}$ values.
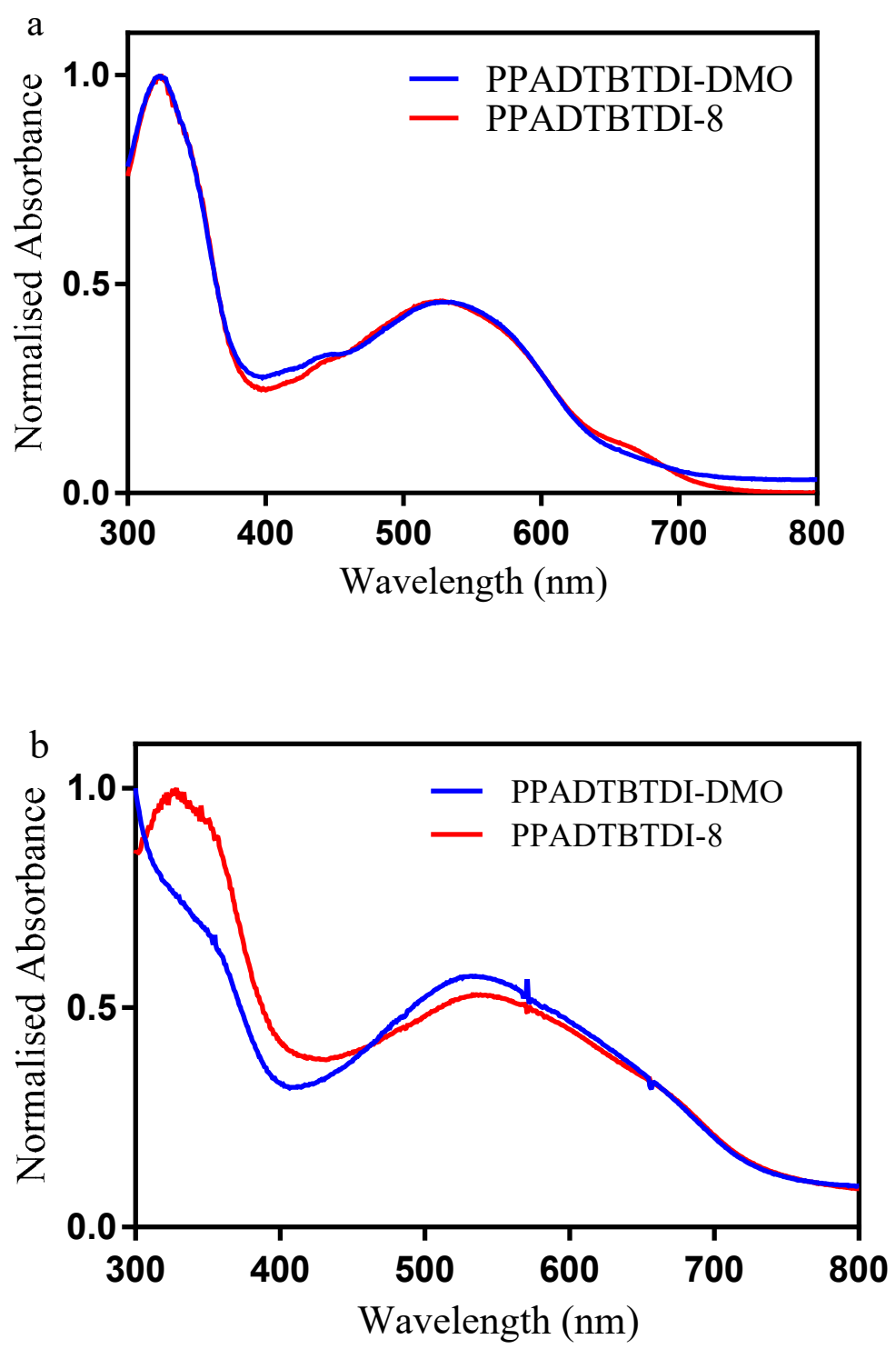

Figure 3. UV-vis absorption spectra of PPADTBTDI-DMO and PPADTBTDI-8 in (a) chloroform solutions; and (b) thin films.

\subsection{Electrochemical Properties}

Cyclic voltammetry was used to study the electrochemical properties of the polymers. The LUMO and HOMO levels of the polymers were calculated from the onsets of the reduction and oxidation potentials, respectively (Figure 4 and Table 3). The onsets were determined from cyclic voltammograms on drop cast polymer films on platinum electrode as working electrode in tetrabutylammonium perchlorate/acetonitrile $(0.1 \mathrm{M})$ vs. $\mathrm{Ag} / \mathrm{Ag}^{+}$reference electrode. PPADTBTDI-DMO shows a reversible oxidation peak, while PPADTBTDI-8 displays an irreversible oxidation peak. Both polymers show one reversible reduction peak at higher potential and one irreversible reduction peak at the lower potential. The onset potentials of the first oxidation wave of PPADTBTDI-DMO and PPADTBTDI-8 appeared at 0.79 and $0.81 \mathrm{~V}$ vs. $\mathrm{Ag} / \mathrm{Ag}^{+}$, corresponding to HOMO energy levels of -5.51 and $-5.53 \mathrm{eV}$, respectively. The onset potential of the first reduction wave of PPADTBTDI-DMO and PPADTBTDI-8 appeared at $-1.15 \mathrm{~V}$, corresponding to a LUMO energy level of $-3.56 \mathrm{eV}$. This corresponds to an electrochemical $\mathrm{E}_{\mathrm{g}}$ of 1.95 and 
$1.97 \mathrm{eV}$ for PPADTBTDI-DMO and PPADTBTDI-8, respectively. The HOMO levels of both polymers are comparable. The HOMO energy level is dominated by the nature of the donor unit and as both polymers have the same anthracene donor unit. Both polymers show deep-lying HOMO energy levels which could be beneficial for the chemical stability of the polymers in oxygen and might lead to higher $V_{\mathrm{oc}}$ values when fabricated in $\mathrm{BHJ}$ solar cells as donor materials with fullerene derivatives as acceptor materials. The LUMO levels of both polymers are similar, as both polymers have the same BTDI acceptor units which control the LUMO energy levels in these materials. Substituting the 3,7-dimethyloctyl chain with the $n$-octyl chain on the imide functionality of the BTDI units does not have a major effect on the electrochemical properties of the polymers.

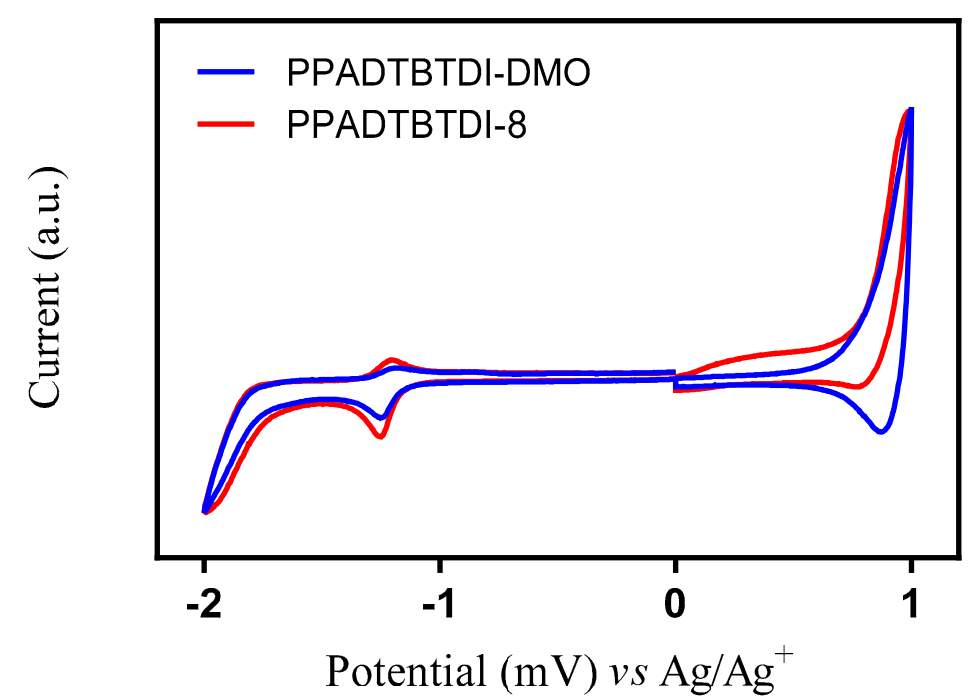

Figure 4. Cyclic voltammograms of PPADTBTDI-DMO and PPADTBTDI-8 on platinum disc electrodes (area $0.031 \mathrm{~cm}^{2}$ ) at a scan rate of $100 \mathrm{mV} \mathrm{s}^{-1}$ in acetonitrile/tetrabutylammonium perchlorate $\left(0.1 \mathrm{~mol} \mathrm{dm}^{-3}\right)$.

Table 3. Thermal and electrochemical properties of the polymers.

\begin{tabular}{ccccccc}
\hline Polymer & $\begin{array}{c}T_{\mathbf{d}} \\
\left({ }^{\circ} \mathbf{C}\right)\end{array}$ & $\begin{array}{c}\mathbf{E}_{\mathbf{o x}} \mathbf{0} \\
\mathbf{( V )}\end{array}$ & $\begin{array}{c}\text { HOMO } \\
(\mathbf{e V})\end{array}$ & $\begin{array}{c}\mathrm{E}_{\text {red }} \mathbf{0} \\
(\mathbf{V})\end{array}$ & $\begin{array}{c}\text { LUMO } \\
(\mathbf{e V})\end{array}$ & $\mathbf{E}_{\mathbf{g}(\text { elec) }}(\mathbf{e V})$ \\
\hline $\begin{array}{c}\text { PPADTBTDI-DMO } \\
\text { PPADTBTDI-8 }\end{array}$ & 354 & 0.79 & -5.51 & -1.15 & -3.56 & 1.95 \\
\hline
\end{tabular}

The HOMO energy levels of PPADTBTDI-DMO and PPADTBTDI-8 are slightly lower than those of PPATBT and PPATBT-8, whereas they are significantly deeper than PPAT2BT8 analogues. The shallower HOMO energy level of PPAT2BT-8 is mainly due to the flanking bithiophene units between the anthracene unit and $(\mathrm{OR})_{2} \mathrm{BT}$ unit, which increase the intramolecular charge transfer along its polymer backbone. PPADTBTDI-DMO and PPADTBTDI-8 have very low-lying LUMO energy levels relative to those of their PPATBT, PPATBT- 8 and PPAT2BT-8 counterparts [21]. This could be explained by the stronger electron-withdrawing ability of BTDI unit than BT and $(\mathrm{OR})_{2} \mathrm{BT}$ moieties. These results could be promising as to the photovoltaic properties of these two polymers in $\mathrm{BHJ}$ solar cells with fullerene derivatives.

\subsection{Thermal Properties}

The thermal properties of the polymers were studied by thermogravimetric analysis (TGA). TGA of PPADTBTDI-DMO and PPADTBTDI-8 did not detect changes below 354 and $313^{\circ} \mathrm{C}$, respectively (Figure 5 and Table 3). The thermal stability of PPADTBTDI-8 
is significantly lower than that of PPADTBTDI-DMO. It is worth noting that the thermal properties of the polymers essentially depend on the type of the alkyl chains was anchored to the imide functionality on the BTDI units. The polymers have thermal stability windows that are well within those used in solar cell applications and could be stable for such use. In previous studies, TGA has been used for evaluating the thermal properties of D-A conjugated polymers for polymer solar cell (PSC) applications [19,22,41-44].

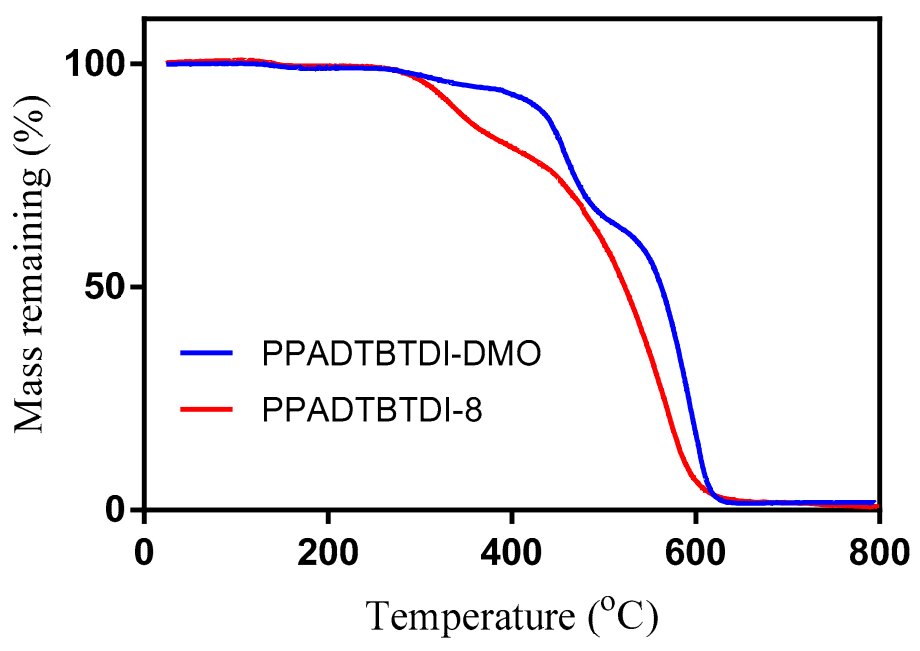

Figure 5. TGA of PPADTBTDI-DMO and PPADTBTDI-8.

\subsection{Powder X-Ray Diffraction (XRD)}

The structural properties of the polymers were studied by powder XRD in the solid state (Figure 6). PPADTBTDI-DMO and PPADTBTDI-8 exhibit a similar diffraction patent with a broad diffraction peak at an angle of $20.0^{\circ}$, corresponding to the $\pi-\pi$ stacking distances between polymer chains of $0.443 \mathrm{~nm}$. This result shows that both polymers have an amorphous nature which are similar to analogous anthracene-based polymers, PTATPD (O), PTATPD (DMO) and PTATPD (BP) [41]. Table 4 lists the symbols and their corresponding physical significances.

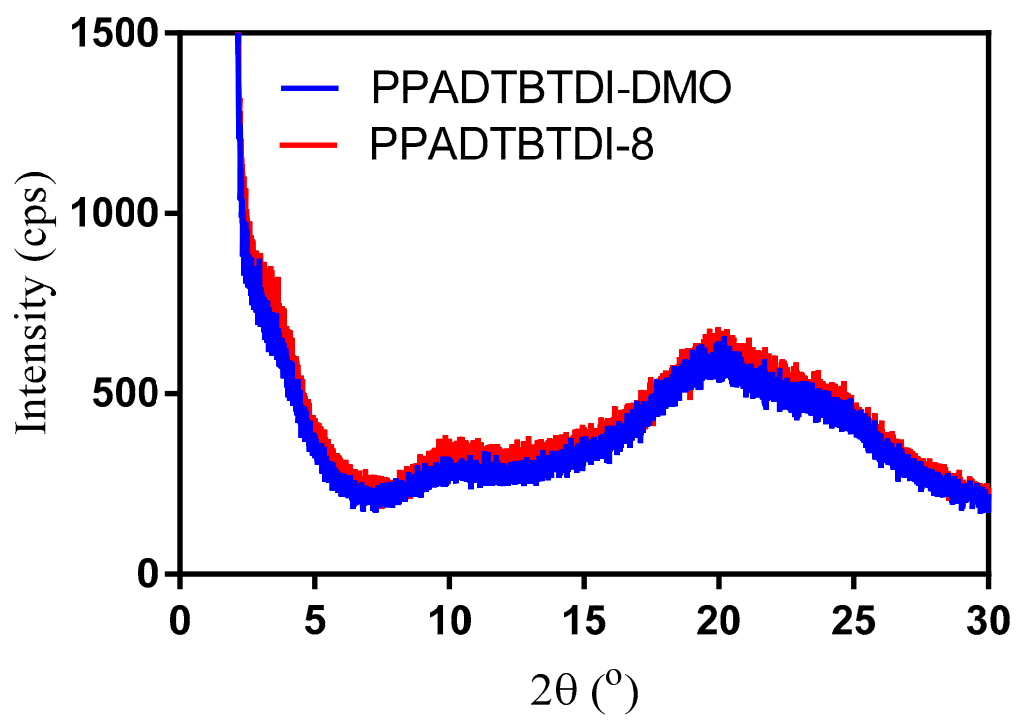

Figure 6. Powder XRD of PPADTBTDI-DMO and PPADTBTDI-8. 
Table 4. Symbols and their corresponding physical significances.

\begin{tabular}{|c|c|}
\hline Symbols & Physical Significances \\
\hline $\mathrm{E}_{\mathrm{g}}$ & Energy gap in $\mathrm{eV}$ \\
\hline $\mathrm{HOMO}$ & Highest occupied molecular orbital level in eV \\
\hline LUMO & Lowest unoccupied molecular orbital in $\mathrm{eV}$ \\
\hline FET & Field effect transistor \\
\hline $\mathrm{BHJ}$ & Bulk heterojunction \\
\hline $\mathrm{V}_{\mathrm{oc}}$ & Open-circuit voltage in volts \\
\hline $\mathrm{J}_{\mathrm{sc}}$ & Short-circuit current in ampere \\
\hline PC & Power conversion \\
\hline$\lambda$ & Lambda in $\mathrm{nm}$ \\
\hline $\mathrm{T}_{\mathrm{d}}$ & Degradation temperature in ${ }^{\circ} \mathrm{C}$ ( $5 \%$ weight loss) \\
\hline D-A & Donor-acceptor \\
\hline NBS & $N$-bromosuccinimide \\
\hline DMF & $N, N$-dimethylformamide \\
\hline DCM & Dichloromethane \\
\hline BT & 2,1,3-Benzothiadiazole \\
\hline BTDI & Benzothiadiazole dicarboxylic imide \\
\hline THF & Tetrahydrofuran \\
\hline PPADTBTDI-DMO & $\begin{array}{c}\text { Poly[9,10-bis(4-(dodecyloxy)phenyl)-2,6-anthracene-alt-5,5-(4', } 7^{\prime} \text {-bis(2-thienyl)-2' }, 1^{\prime}, 3^{\prime} \text {-benzothiadiazole- } N \text { - } \\
\text { 5,6-(3,7-dimethyloctyl)dicarboxylic } \\
\text { imide)] }\end{array}$ \\
\hline PPADTBTDI-8 & $\begin{array}{c}\text { Poly[9,10-bis(4-(dodecyloxy)phenyl)-2,6-anthracene-alt-5,5-(4', } 7^{\prime} \text {-bis(2-thienyl)-2' }, 1^{\prime}, 3^{\prime} \text {-benzothiadiazole- } \\
\text { 5,6-N-octyl-dicarboxylic } \\
\text { imide })]\end{array}$ \\
\hline XRD & Powder X-ray diffraction \\
\hline PSC & Polymer solar cell \\
\hline PDPP-FAF & Poly[3,6-difuran-2-yl-2,5-di(2-octyldodecyl)-pyrrolo[3,4-c]pyrrole-1,4-dione-alt-anthracene] \\
\hline РPATBT & $\begin{array}{l}\operatorname{Poly}\left(9,10-\text { bis(4-(dodecyloxy)phenyl)-anthracene-2,6-diyl-alt-(4,7-dithiophen-2-yl)-2', } 1^{\prime}, 3^{\prime}-\right. \\
\text { benzothiadiazole-5,5-diyl] }\end{array}$ \\
\hline PРATBT-8 & $\begin{array}{l}\operatorname{Poly}(9,10-\text { bis(4-(dodecyloxy)phenyl)-anthracene-2,6-diyl-alt-(5,6-bis(octyloxy)-4,7-di(thiophen-2- } \\
\text { yl)benzo[c][1,2,5]thiadiazole-5,5-diyl] }\end{array}$ \\
\hline PРAT2BT-8 & $\begin{array}{l}\operatorname{Poly}(9,10-\text { bis(4-(dodecyloxy)phenyl)-anthracene-2,6-diyl-alt-(5,6-bis(octyloxy)-4,7-di(2,2'-bithiophen-5- } \\
\text { yl)benzo[c][1,2,5] } \\
\text { thiadiazole)-5,5-diyl] }\end{array}$ \\
\hline PTATffBT & $\begin{array}{l}\text { Poly[9,10-bis(triisopropylsilylacetylene)-anthracene-2,6-diyl-alt-(4,7-dithiophen-2-yl)-5,6- } \\
\text { difluorobenzo[c][1,2,5]thiadiazole-5-5-diyl] }\end{array}$ \\
\hline PhNSO & $N$-thionyl aniline \\
\hline TMSCl & Trimethylsilyl chloride \\
\hline M1 & 4,7-Di(5-bromo-thien-2-yl)-2,1,3-benzothiadiazole-5,6-N-(3,7-dimethyloctyl)dicarboxylic imide \\
\hline M2 & 4,7-Di(5-bromo-thien-2-yl)-2,1,3-benzothiadiazole-5,6- $N$-octyl-dicarboxylic imide \\
\hline GPC & Gel permeation chromatography \\
\hline PTATBT-8 & $\begin{array}{l}\text { Poly[9,10-bis(triisopropylsilylacetylene)-anthracene-2,6-diylalt-(5,6-bis(octyloxy)-4,7-di(thiophene-2- } \\
\text { yl)benzo[c]thiadiazole-5,5-diyl] }\end{array}$ \\
\hline
\end{tabular}

\section{Conclusions}

Two low band gap alternating copolymers comprising of 2,6-linked anthracene moieties flanked by thienyl units as electron donor units and benzothiadiazole dicarboxylic imide (BTDI) as electron acceptor units were synthesised through Suzuki polymerisation, and yielded PPADTBTDI-DMO and PPADTBTDI-8. Both polymers were prepared in good yields and show good solubility in common organic solvents. Both polymers have comparable $M_{n}$ values for both toluene and chloroform fractions. The $M_{n}$ values of the toluene fractions of the polymers are about $6000 \mathrm{~g} \mathrm{~mol}^{-1}$ which are relatively low. However, the $M_{\mathrm{n}}$ values of the chloroform fractions of the polymers are higher than $12,000 \mathrm{~g} \mathrm{~mol}^{-1}$. Both polymers show absorption maxima around $540 \mathrm{~nm}$ in chloroform solutions with shoulder absorption bands at about $635 \mathrm{~nm}$. The shoulder absorption peak could be attributed to intermolecular interactions between the polymer chains and a certain degree of their 
aggregation in solutions. In thin films, the absorption spectra of the polymers show slightly bathochromic shift absorption maxima with a stronger shoulder at $660 \mathrm{~nm}$ relative to their absorption in solutions. This is related to those polymers adopting a more planar structure in thin-films. The $\mathrm{E}_{\mathrm{g}}$ of the polymers are low $\left(\mathrm{E}_{\mathrm{g}}=1.66 \mathrm{eV}\right)$ which could be beneficial to obtain high $J_{\mathrm{sc}}$ values in $\mathrm{BHJ}$ solar cells. The HOMO levels of both polymers are comparable because the HOMO energy level is controlled by the nature of the donor unit and both polymers have the same anthracene donor units. Both polymers show low-lying HOMO energy levels of about $-5.5 \mathrm{eV}$ which could be useful for the chemical stability of the polymers in oxygen and could lead to high $V_{\text {oc }}$ values when fabricated in BHJ solar cells as donor materials with fullerene derivatives as acceptor materials. The LUMO energy levels of both polymers are similar, as both polymers have the same BTDI acceptor units which dominate the LUMO levels in these materials. Both polymers could show good thermal stability with $\mathrm{T}_{\mathrm{d}}$ surpass $310^{\circ} \mathrm{C}$. Attaching different solubilizing chains (3,7-dimethyloctyl vs. $n$-octyl) on BTDI moieties has a little impact on the molecular weights and optoelectronic properties of the polymers. The TGA of PPADTBTDI-DMO and PPADTBTDI-8 did not prove instability with decomposition temperatures of 354 and $313{ }^{\circ} \mathrm{C}$, respectively. The powder XRD of the polymers showed diffraction peaks at $20.0^{\circ}$ corresponding to the $\pi-\pi$ stacking distance of $0.443 \mathrm{~nm}$. Both polymers have the amorphous nature in the solid state, which could be employed as electrolytes in energy devices.

Author Contributions: Conceptualisation, A.I.; formal analysis, A.R.M.; investigation, A.R.M. and M.S.A.; methodology, A.R.M., M.S.A. and S.N.A.; project administration, A.I. and S.B.A.; supervision, A.I.; validation, S.B.A., M.S.A., S.N.A. and M.A.B.; writing—original draft, A.R.M.; writing-review and editing, A.I., S.B.A., M.S.A., S.N.A. and M.A.B. All authors have read and agreed to the published version of the manuscript.

Funding: This research received no external funding.

Acknowledgments: The authors appreciatively acknowledge all support for this work by the University of Sheffield, University of Sulaimani, and Charmo University.

Conflicts of Interest: The authors declare no conflict of interest.

\section{References}

1. Murad, A.R.; Iraqi, A.; Aziz, S.B.; Abdullah, S.N.; Brza, M.A. Conducting Polymers for Optoelectronic Devices and Organic Solar Cells: A Review. Polymers 2020, 12, 2627. [CrossRef]

2. Wang, H.; Liu, Q.; Liu, D.; Su, R.; Liu, J.; Li, Y. Computational Prediction of Electronic and Photovoltaic Properties of AnthraceneBased Organic Dyes for Dye-Sensitized Solar Cells. Int. J. Photoenergy 2018, 2018, 4764830. [CrossRef]

3. Allard, S.; Forster, M.; Souharce, B.; Thiem, H.; Scherf, U. Organic Semiconductors for Solution-Processable Field-Effect Transistors (OFETs). Angew. Chem. Int. Ed. 2008, 47, 4070-4098. [CrossRef] [PubMed]

4. Marinov, O.; Deen, M.J.; Zschieschang, U.; Klauk, H. Organic Thin-Film Transistors: Part I—Compact DC Modeling. IEEE Trans. Electron. Dev. 2009, 56, 2952-2961. [CrossRef]

5. Kraft, A.; Grimsdale, A.C.; Holmes, A.B. Electroluminescent Conjugated Polymers-Seeing Polymers in a New Light. Angew. Chem. Int. Ed. 1998, 37, 402-428. [CrossRef]

6. $\quad$ Burroughes, J.H.; Bradley, D.D.C.; Brown, A.R.; Marks, R.N.; Mackay, K.; Friend, R.H.; Burns, P.L.; Holmes, A.B. Light-emitting diodes based on conjugated polymers. Nature 1990, 347, 539-541. [CrossRef]

7. Brabec, C.J.; Gowrisanker, S.; Halls, J.J.M.; Laird, D.; Jia, S.; Williams, S.P. Polymer-Fullerene Bulk-Heterojunction Solar Cells. Adv. Mater. 2010, 22, 3839-3856. [CrossRef]

8. Pope, M.; Kallmann, H.P.; Magnante, P.C. Electroluminescence in Organic Crystals. J. Chem. Phys. 1963, 38, 2042-2043. [CrossRef]

9. Chien, C.-T.; Lin, C.-C.; Watanabe, M.; Lin, Y.-D.; Chao, T.-H.; Chiang, T.-C.; Huang, X.-H.; Wen, Y.-S.; Tu, C.-H.; Sun, C.-H.; et al. Tetracene-based field-effect transistors using solution processes. J. Mater. Chem. 2012, 22, 13070-13075. [CrossRef]

10. Kim, H.; Lee, D.Y.; Lee, S.G.; Cho, K. High-Mobility Organic Single-Crystal Microtubes of Soluble Pentacene Semiconductors with Hollow Tetragonal Structures. Chem. Mater. 2012, 24, 2752. [CrossRef]

11. Clemente, R.; Chica, E.; Peñuela, G.A. Photovoltaic array for powering advanced oxidation processes: Sizing, application and investment costs for the degradation of a mixture of anthracene and benzo[a]pyrene in natural water by the $\mathrm{UV} / \mathrm{H}_{2} \mathrm{O}_{2}$ system. $J$. Environ. Chem. Eng. 2018, 6, 2751-2761. [CrossRef]

12. Gong, X.; Li, C.; Lu, Z.; Li, G.; Mei, Q.; Fang, T.; Bo, Z. Anthracene-Containing Wide-Band-Gap Conjugated Polymers for High-Open-Circuit-Voltage Polymer Solar Cells. Macromol. Rapid Commun. 2013, 34, 1163-1168. [CrossRef] [PubMed] 
13. Jung, J.W.; Liu, F.; Russell, T.P.; Jo, W.H. Anthracene-Based Medium Bandgap Conjugated Polymers for High Performance Polymer Solar Cells Exceeding 8\% PCE without Additive and Annealing Process. Adv. Energy Mater. 2015, 5, 11. [CrossRef]

14. Zhou, H.; Yang, L.; Stoneking, S.; You, W. A weak donor-strong acceptor strategy to design ideal polymers for organic solar cells. ACS Appl. Mater. Interface 2010, 2, 1377-1383. [CrossRef]

15. Feng, H.; Yi, Y.Q.Q.; Ke, X.; Yan, J.; Zhang, Y.; Wan, X.; Li, C.; Zheng, N.; Xie, Z.; Chen, Y. New Anthracene-Fused Nonfullerene Acceptors for High Efficiency Organic Solar Cells: Energy Level Modulations Enabling Match of Donor and Acceptor. Adv. Energy Mater. 2019, 9, 1803541. [CrossRef]

16. Chung, S.; Lee, D.H.; Cho, N.S.; Park, C.E. New anthracene-thiophene-based copolymers that absorb across the entire UV-vis spectrum for application in organic solar cells. Chem. Commun. 2010, 46, 1863-1865.

17. Chen, H.-Y.; Chen, C.-T.; Chen, C.-T. Synthesis and characterization of a new series of blue fluorescent 2, 6-linked 9, 10diphenylanthrylenephenylene copolymers and their application for polymer light-emitting diodes. Macromolecules 2010, 43, 3613-3623. [CrossRef]

18. Back, J.Y.; An, T.K.; Cheon, Y.R.; Cha, H.; Jang, J.; Kim, Y.; Baek, Y.; Chung, D.S.; Kwon, S.-K.; Park, C.E. Alkyl Chain Length Dependence of the Field-Effect Mobility in Novel Anthracene Derivatives. ACS Appl. Mater. Interfaces 2015, 7, 351-358. [CrossRef]

19. Liu, C.; Cai, W.; Guan, X.; Duan, C.; Xue, Q.; Ying, L.; Huang, F.; Cao, Y. Synthesis of donor-acceptor copolymers based on anthracene derivatives for polymer solar cells. Polym. Chem. 2013, 4, 3949-3958. [CrossRef]

20. Sonar, P.; Singh, S.P.; Williams, E.L.; Li, Y.; Soh, M.S.; Dodabalapur, A. Furan containing diketopyrrolopyrrole copolymers: Synthesis, characterization, organic field effect transistor performance and photovoltaic properties. J. Mater. Chem. 2012, 22, 4425-4435. [CrossRef]

21. Almeataq, M.S.; Yi, H.; Al-Faifi, S.; Alghamdi, A.A.B.; Iraqi, A.; Scarratt, N.W.; Wang, T.; Lidzey, D.G. Anthracene-based donor-acceptor low band gap polymers for application in solar cells. Chem. Commun. 2013, 49, 2252-2254. [CrossRef]

22. Cartwright, L.; Taylor, L.J.; Yi, H.; Iraqi, A.; Zhang, Y.; Scarratt, N.W.; Wang, T.; Lidzey, D.G. Triisopropylsilylacetylenefunctionalised anthracene-alt-benzothiadiazole copolymers for application in bulk heterojunction solar cells. RSC Adv. 2015, 5, 101607-101615. [CrossRef]

23. Jung, J.W.; Jo, W.H. A low band-gap copolymer composed of thienyl substituted anthracene and diketopyrrolopyrrole compatible with multiple electron acceptors for high efficiency polymer solar cells. Polym. Chem. 2015, 6, 4013-4019. [CrossRef]

24. Ponomarenko, S.; Muzafarov, A.; Borshchev, O.; Vodopyanov, E.; Demchenko, N.; Myakushev, V. Synthesis of bithiophenesilane dendrimer of the first generation. Russ. Chem. Bull. 2005, 54, 684-690. [CrossRef]

25. Wen, L.; Rasmussen, S.C. Synthesis and structural characterization of 2,5-dihalo-3,4-dinitrothiophenes. J. Chem. Crystallogr. 2007, 37, 387-398. [CrossRef]

26. Kenning, D.; Mitchell, K.A.; Calhoun, T.R.; Funfar, M.R.; Sattler, D.J.; Rasmussen, S.C. Thieno [3,4-b] pyrazines: Synthesis, structure, and reactivity. J. Org. Chem. 2002, 67, 9073-9076. [CrossRef]

27. McNamara, L.E.; Liyanage, N.; Peddapuram, A.; Murphy, J.S.; Delcamp, J.H.; Hammer, N.I. Donor-Acceptor-Donor Thienopyrazines via Pd-Catalyzed C-H Activation as NIR Fluorescent Materials. J. Org. Chem. 2016, 81, 32-42. [CrossRef]

28. Schwiderski, R.L.; Rasmussen, S.C. Synthesis and Characterization of Thieno [3,4-b] pyrazine-Based Terthienyls: Tunable Precursors for Low Band Gap Conjugated Materials. J. Org. Chem. 2013, 78, 5453-5462. [CrossRef]

29. Hailu, H.; Atsbeha, B.; Admassie, S.; Mammo, W.; Raju, V.; Chebude, Y. Variable denticity of a multidentate terthiophene derivative towards Ni (II) and Zn (II)-structural studies. Bull. Chem. Soc. Ethiop. 2011, 25, 221-231. [CrossRef]

30. Delgado, M.R.; Hernandez, V.; Navarrete, J.L.; Tanaka, S.; Yamashita, Y. Combined spectroscopic and theoretical study of narrow band gap heterocyclic co-oligomers containing alternating aromatic donor and o-quinoid acceptor units. J. Phys. Chem. 2004, 108, 2516-2526. [CrossRef]

31. Wang, L.; Cai, D.; Zheng, Q.; Tang, C.; Chen, S.-C.; Yin, Z. Low Band Gap Polymers Incorporating a Dicarboxylic Imide-Derived Acceptor Moiety for Efficient Polymer Solar Cells. ACS Macro Lett. 2013, 2, 605-608. [CrossRef]

32. Nielsen, C.B.; Ashraf, R.S.; Treat, N.D.; Schroeder, B.C.; Donaghey, J.E.; White, A.J.; Stingelin, N.; McCulloch, I. 2,1,3Benzothiadiazole-5,6-Dicarboxylic Imide-A Versatile Building Block for Additive-and Annealing-Free Processing of Organic Solar Cells with Efficiencies Exceeding 8\%. Adv. Mater. 2015, 27, 948-953. [CrossRef] [PubMed]

33. Lan, L.; Chen, Z.; Li, Y.; Ying, L.; Huang, F.; Cao, Y. Donor-acceptor conjugated polymers based on cyclic imide substituted quinoxaline or dibenzo[a,c]phenazine for polymer solar cells. Polym. Chem. 2015, 6, 7558-7569. [CrossRef]

34. Matsueda, Y.; Xu, S.; Negishi, E.-i. A novel highly enantio-and diastereoselective synthesis of vitamin E side-chain. Tetrahedron Lett. 2015, 56, 3346-3348. [CrossRef]

35. Thomson, A.; O'Connor, S.; Knuckley, B.; Causey, C.P. Design, synthesis, and in vitro evaluation of an activity-based protein profiling (ABPP) probe targeting agmatinedeiminases. Bioorg. Med. Chem. 2014, 22, 4602-4608. [CrossRef]

36. Yue, W.; Zhao, Y.; Shao, S.; Tian, H.; Xie, Z.; Geng, Y.; Wang, F. Novel NIR-absorbing conjugated polymers for efficient polymer solar cells: Effect of alkyl chain length on device performance. J. Mater. Chem. 2009, 19, 2199-2206. [CrossRef]

37. Yi, H.; Al-Faifi, S.; Iraqi, A.; Watters, D.C.; Kingsley, J.; Lidzey, D.G. Carbazole and thienyl benzo [1,2,5] thiadiazole based polymers with improved open circuit voltages and processability for application in solar cells. J. Mater. Chem. 2011, 21, 13649-13656. [CrossRef] 
38. Murad, R.; Iraqi, A.; Aziz, S.B.; Abdullah, S.N.; Abdulwahid, R.T.; Hussen, S.A. Optical, Electrochemical, Thermal, and Structural Properties of Synthesized Fluorene/Dibenzosilole-Benzothiadiazole Dicarboxylic Imide Alternating Organic Copolymers for Photovoltaic Applications. Coatings 2020, 10, 1147. [CrossRef]

39. Murad, R.; Iraqi, A.; Aziz, S.B.; Hi, H.; Abdullah, S.N.; Brza, M.A.; Abdulwahid, R.T. Influence of Fluorine Substitution on the Optical, Thermal, Electrochemical and Structural Properties of Carbazole-Benzothiadiazole Dicarboxylic Imide Alternate Copolymers. Polymers 2020, 12, 2910. [CrossRef]

40. Li, Y.; Zou, Y. Conjugated polymer photovoltaic materials with broad absorption band and high charge carrier mobility. Adv. Mater. 2008, 20, 2952-2958. [CrossRef]

41. Cartwright, L.; Neal, T.J.; Rutland, N.J.; Iraqi, A. Anthracene-thieno[3,4-c]pyrrole-4,6-dione based donor-acceptor conjugated copolymers for applications in optoelectronic devices. Polym. Adv. Technol. 2016, 27, 525-531. [CrossRef]

42. Cartwright, L.; Iraqi, A.; Zhang, Y.; Wang, T.; Lidzey, D.G. Impact of fluorine substitution upon the photovoltaic properties of benzothiadiazole-fluorene alternate copolymers. RSC Adv. 2015, 5, 46386-46394. [CrossRef]

43. Cartwright, L.; Yi, H.; Iraqi, A. Effect of fluorination pattern and extent on the properties of PCDTBT derivatives. New J. Chem. 2016, 40, 1655-1662. [CrossRef]

44. Murad, R.; Iraqi, A.; Aziz, S.B.; Abdullah, S.N.; Abdulwahid, R.T. Synthesis, Optical, Thermal and Structural Characteristics of Novel Thermocleavable Polymers Based on Phthalate Esters. Polymers 2020, 12, 2791. [CrossRef] [PubMed] 